1982

\title{
Ethical Issues in the Representation of Individuals in the Commitment Process
}

Michael L. Perlin

New York Law School, michael.perlin@nyls.edu

Robert Sadoff

Follow this and additional works at: https://digitalcommons.nyls.edu/fac_articles_chapters

Part of the Civil Rights and Discrimination Commons, Legal Ethics and Professional Responsibility Commons, and the Legal Profession Commons

\section{Recommended Citation}

Law and Contemporary Problems, Vol. 45, Issue 3 (Summer 1982), pp. 161-192

This Article is brought to you for free and open access by the Faculty Scholarship at DigitalCommons@NYLS. It has been accepted for inclusion in Articles \& Chapters by an authorized administrator of DigitalCommons@NYLS. 


\title{
ETHICAL ISSUES IN THE REPRESENTATION OF INDIVIDUALS IN THE COMMITMENT PROCESS*
}

\author{
Michael L. Perlin, EsQ. $\dagger$ \\ AND ROBERT L. SADOFF, M.D.**
}

\section{INTRODUCTION}

The right to counsel is one of those "immutable principles of justice which inhere in the idea of free government,"' and which has been characterized as "the cornerstone of the American judicial system."' Since mentally handicapped citizens are traditionally seen as persons "to whom attention need not be paid,"3 the need for counsel is "magnified" 4 in civil commitment cases to insure "that there is someone on the 'outside" " concerned about the handicapped person's fate. ${ }^{5}$ Unfortunately, the record of the legal profession in providing services to the mentally ill has been grossly inadequate. ${ }^{6}$ In addition, collateral questions concerning the specific ethical issues arising in the representation of persons perceived as mentally handicapped in the involuntary civil commitment process receive scant attention.7 These ethical issues spawn many subissues: Are ethical standards for

Copyright () 1983 by Law and Contemporary Problems

* The views expressed herein are strictly the authors' own, and do not necessarily reflect those of the departments or universities with which they are affiliated.

$\dagger$ Director, Division of Mental Health Advocacy, Department of the Public Advocate, Trenton, New Jersey.

** Clinical Professor of Psychiatry, University of Pennsylvania; Lecturer in Law, Villanova School of Law, Philadelphia, Pennsylvania.

1. Powell v. Alabama, 287 U.S. 45, 71 (1932) (quoting Holden v. Hardy, 169 U.S. 366, 389 (1898)).

2. 4 Appendix, Task Panel Reports Submitted to the President's Commission on Mental Health 1353, 1366 (1978) [hereinafter cited as TASK Panel Reports].

3. Wald, Basic Personal and Ciuil Rights, in The Mentally Retarded Crtizen and the Law 3, 18 (1976).

4. TASK PANel Reports, supra note 2.

5. Ellis, Volunteering Children: Parental Commitment of Minors to Mental Institutions, 62 CALIF. L. Rev. 840, 890 (1974).

6. See, e.g., N. Kittrie, The Right to be Different 92 (1973) ("superficial and totally inadequate'); Cohen, The Function of the Altomey and the Commitment of the Mentally Ill, 44 TEX. L. Rev. 424, 448 (1966) ("perfunctory'); Weihofen, Mental Health Services for the Poor, 54 CALIF. L. REV. 920, 939 (1966) ("passive"). See generally Perlin, Representing Individuals in the Commitment and Guardianship Process, in 1 LEGAL Rights of Mentally Disabled Persons 497 (P. Friedman ed. 1979) (hereinafter cited as Representing Individuals]; Van Ness \& Perlin, Mental Health Advocacy-The New Jersey Experience, in MENTAL Health AdVOCACY: AN EMERging Force in CONSUMERs' Righrs 62, 63, 68-69 (1977) [hereinafter cited as The New Jersey Experience ]; articles cited infra notes 31-39.

7. While there is ample literature dealing with virtually every substantive mental health rights issue, see, e.g., TASK PANEL REPORTs, supra note 2, at $1422 \mathrm{n} .10$ (right to treatment) and id. at $1431 \mathrm{n} .1$ (right to refuse treatment), there have been few articles on the question of ethical issues. Among the best are Mickenberg, The Silent Clients: Legal and Ethical Considerations in Representing Severely and Profoundly Retarded 
lawyers representing the mentally handicapped different from those for other attorneys? How does the lawyer's role differ in such proceedings? Are competency of counsel standards different? Are there special Canons of Ethics applicable to such proceedings? Are the courts even interested in the ethical issues in the entire process?

Indeed, ethical issues in representation of the handicapped are notably underdiscussed. Although the Canons of Professional Responsibility and the Disciplinary Rules of the American Bar Association Code of Professional Responsibility counsel attorneys to represent clients "zealously within the bounds of the law" and to "seek the lawful objectives of [their] client[s],"9 they are silent on specific ethical implications of representing disabled clients (or those "perceived"10 to be disabled). ${ }^{11}$ Only a handful of cases even discuss the dimensions of the role played by the attorney in representing handicapped persons. ${ }^{12}$ Even those (relatively few) statutes which make specific provision for counsel for mentally handicapped persons do not allude to specific ethical issues. ${ }^{13}$

This paucity of legal scholarship, case law, and statute probably results from a composite of factors. First, the principle of "out-of-sight, out-of-mind" appears directly applicable, as mentally handicapped individuals are egregiously underrepresented in all phases of the legal process ${ }^{14}$ and are rarely afforded specialized counsel. ${ }^{15}$ Those few handicapped persons who do have counsel are afraid of "rocking the boat," and ethical questions thus will not be fully aired. ${ }^{16}$ And, since the underlying legal principles mandating representation of handicapped persons at commitment proceedings may still be seen as somewhat uncertain, ${ }^{17}$ problems

Individuals, 31 Stan. L. Rev. 625 (1979) and Brakel, The Role of the Lawyer in the Menial Health Field, 1977 AM. BAR FOUND. RES. J. 467. An excellent overall review of issues involved in the representation of mentally handicapped persons is S. Herr, The NEW Clients: Legal Services for Mentally Retarded Persons (1979).

8. Model Code of Professional Responsibility Canon 7 (1979).

9. Id. DR 7-101 (1979).

10. The issue of "perception" is not an unimportant one. Although similar language is used by the President's Commission's Task Force (counsel should be provided on matters "related to the existence-or perceived existence-Of a handicap," TASK PANEL REPORTS, supra note 2, at 1368), it is not replicated in the statutes. Cf., e.g., 42 U.S.C.A. \$ 9501 (West Supp. 1981).

11. But see Model Rules of Professional Conduct Rule 1.14 commentary at $94-97$ (Proposed Final Draft 1981), discussed extensively infra at text accompanying notes 159-83.

12. See, e.g., Lessard v. Schmidt, 349 F. Supp. 1078, 1099 (E.D. Wis. 1972), vacated on other grounds, 414 U.S. 473 (1973), on remand, 379 F. Supp. 1376 (E.D. Wis. 1974), vacated and remanded on other grounds, 421 U.S. 957 (1975), reinstated, 413 F. Supp. 1318 (E.D. Wis. 1976); Suzuki v. Quisenberry, 411 F. Supp. 1113,1129 (D. Hawaii 1976), supp. sub nom. Suzuki v. Yuen, 438 F. Supp. 1106 (D. Hawaii 1977), affd in part, rev'd in part and dismissed in part on other grounds, 617 F.2d 173 (9th Cir. 1980); Lynch v. Baxley, 386 F. Supp. 378,389 (M.D. Ala. 1974).

13. See, e.g., N.J. STAT. ANN. \$§ 52:27E-21 to 27 (West 1980); see also 42 U.S.C.A. § 9501(1)(M)(i) (iii); 42 U.S.C.A. $\$ 9502$ (repealed, Pub. L. No. 97-35, $§ 9021$ (e)(1), 95 Stat. 560 (1981)).

14. TASK PANEL RePORTS, supra note 2.

15. See infra text accompanying notes $26-60$.

16. Cf. Perlin, Rights of Ex-Patients in the Community: The Next Frontier?, 8 Bull. AM. ACAD. PsychIATRY \& L. 33, 38 (1980) (explanation of why few cases are litigated by former inpatients against community aftercare facilities).

17. Thus, the United States Supreme Court declined to hold in Vitek v. Jones, 445 U.S. 552 (1980), that there is an absolute constitutional right to counsel at commitment hearings; rather, it ruled that in matters involving prison to hospital transfers, due process will be satisfied if the inmate is provided "qualified and independent assistance." Id. at 497, 500 (Powell, J., concurring in part, and speaking for a 
involving ethical issues will inevitably be placed on the "back burner" until the substantive and procedural issues are resolved more definitively.

Secondly, the ethical issues which are raised serve to trigger issues which legislators and judges do not like to confront. It is this discomfort which has, perhaps, served as a brake on judicial creativity in insanity defense matters. ${ }^{18}$ Similarly, the issues raised by investigating ethical standards in civil commitment representation may dredge up unconscious feelings which lead to avoidance-by clients, by lawyers, and by judges - of the underlying problems. ${ }^{19}$

More attention to the ethical issues in question is both appropriate and likely. First, the issues referred to involve the gestalt of the entire commitment process: If the attorney cannot present a client's views "in the same traditional, adversarial, partisan role . . . that is the hallmark of the American judicial system," 20 then a serious question arises as to how meaningful any representation can be, especially in a fact setting in which the client's decision-making competence is inevitably and constantly (albeit sometimes improperly) before the court. ${ }^{21}$ Secondly, as time passes and more mentally handicapped persons are afforded legal representation, ${ }^{22}$ such representation will likely become diffused. More and more lawyers will represent handicapped persons before more and more judges. One likely outcome of this infusion of new participants is that the ethical questions discussed here may well receive more extensive consideration as additional courts are faced with these problems.

A topic that is considered even less frequently might appear, initially, to be a subset of the problem referred to above: What are the ethical issues to be faced by a psychiatrist (or other expert witness) who participates in the civil commitment process? ${ }^{23}$ There are, however, other issues which demand discrete attention and consideration; e.g., what are the ethical concerns for such a witness when participation is triggered by a court request or by the committing agency? How are conflicts between the lawyer's ethical precepts and the codes regulating mental health professionals to be resolved? ${ }^{24}$

Consideration of the significant ethical issues requires examination of the

majority of the court on this point). Although, clearly, nonprisoners cannot have fewer due process rights than prisoners in such matters, see, e.g., Rennie v. Klein, 653 F.2d 836, 844 (3d Cir. 1981), vacated and remanded, $102 \mathrm{~S}$. Ct. 3506 (1982), the issue is still to some extent an open one. See also Addington v. Texas, 441 U.S. 418, 427-30 (1979) (distinguishing civil commitment from criminal prosecution).

18. See generally Perlin \& Sadoff, The Adversary Process, in Violence: Perspectives on Murder and AGGRESSION 394, 401-03 (1978).

19. See, e.g., Perlin, Psychiatric Testimony in a Criminal Setting, 3 Bull. AM. ACad. Psych. \& L. 143, 147 48 (1975).

20. Representing Individuals, supra note 6 , at 506 .

21. See, e.g., Rennie v. Klein, 653 F.2d 836, 846 \& n.12 (3d Cir. 1981), vacated and remanded, 102 S. Ct. 3506 (1982).

22. See, e.g., TASK PANEL. RePORTS, supra note 2, at 1366-67.

23. Although the issues in question are discussed to some extent in R. SADOFF, Forensic PSYchiATRY 47-58 (1975), a search of the legal literature reveals no article focusing specifically on this problem.

24. Some of the issues in question are discussed, from differing perspectives, in Anderten, Staulcup \& Grisso, On Being Ethical in Legal Places, 11 Prof. Psycology 764 (1980); Berger, Expert Clinical Testimony and Professional Ethics, 7 J. Psychiatr y \& L. 347 (1979); Murray, Ethical Issues in a State Psychiatric Hospital, 9 Psychiatric Annals 111 (1979); Weinstein, Psychiatry on Trial: Clinical and Ethical Problems in the Psychiatric Assessment of Competency to Stand Trial, 347 ANNALS N.Y. ACAD. SCI. 12 (1980). 
problem through two different filters - the lawyer's views and the mental health professional's views - as well as through both together. Such analyses should be helpful in assessing the impact, if any, of the varying professional perspectives. ${ }^{25}$

\section{II}

\section{THE LAWYER'S VIEW}

The title of this article is phrased so that a reader may assume-not unreasonably-that "ethical issues" in the commitment process are perceived, or should be perceived, as different from "ethical issues" in other legal processes. ${ }^{26}$ This assumption does not arise from mere semantics, but may very well go to the heart of the entire process." Whereas the historic role of the lawyer has been "not merely a neutral adviser to the courts but [that of] the ardent defender of the client's rights and freedoms," 28 the record of counsel providing services to the mentally ill has never lived up to this standard. ${ }^{29}$

Before 1975 all surveys were unanimous:

[T]raditional, sporadically-appointed counsel in mental health cases [were] unwilling to pursue necessary investigations, lack[ed] . . . expertise in dealing with mental health problems, and . . . suffered from "rolelessness," stemming from near-total capitulation to experts, hazily defined concept[s] of success/failure, inability to generate professional or personal interest in [the] patient's dilemma, and lack of [a] clear definition of [the] proper advocacy function. As a result, counsel . . functioned "as no more than a clerk, ratifying the events that transpire[d], rather than influencing them." 30

Individual studies were appalling: A St. Louis survey from the 1960's showed that patients were released in only two of 1700 "contested cases." 31 Similarly, an analysis of three politically dissimilar, geographically noncontiguous states found counsel so inadequate that a patient's chances for release at a commitment hearing were worse with counsel present. ${ }^{32}$

This pathetic record, of course, raises a paradox within a paradox: Lawyers are traditionally zealous in their representation of clients in testamentary capacity cases, traumatic injury actions, and insanity defense trials, all areas in which mental health professional witnesses are regularly subjected to intensive and exhaustive cross-examination. However, lawyers continue to avoid challenging expert testimony in matters involving representation at commitment hearings. ${ }^{33}$

25. For an excellent overview of some of the ethical issues involved, see TASK PANEL REPORTS, supra note 2, at 1473-89; Roth, To Respect Persons, Families, and Communities: Some Problems in the Ethics of Mental Health Care, Psych. Digest, Oct. 1979, at 17.

26. Representing Individuals, supra note 6 , at 500 .

27. See, e.g., Brakel, Legal Problems of People in Mental and Penal Institutions: An Exploratory Study, 1978 AM. BaR Found. Res. J. 565; Brakel, supra note 7; Perlin \& Siggers, The Role of the Lauyer in Mental Heallh Advocacy, 4 Bull. Am. ACAD. Psychiatry \& L. 204 (1976); Van Ness \& Perlin, supra note 6.

28. Andalman \& Chambers, Effective Counsel for Persons Facing Civil Commitment: A Survey, A Polemic, and A Proposal, 45 Miss. L.J. 43, 46 (1974).

29. See sources cited supra note 6 . 63).

30. Representing Individuals, supra note 6, at 501 (quoting, in part, Van Ness \& Perlin, supra note 6, at

31. Dix, Acute Psychiatric Mospitalization of the Mentally III in the Metropolis: An Empirical Study, 1965 WASH. U.L. REV. 485, 540.

32. Andalman \& Chambers, supra note 28 , at 72.

33. See, e.g., Special Project: The Administration of Psychialric Justice: Theory and Practice in Arizona, 13 ARIZ. 
"[N]early every attorney" interviewed in a 1966 survey took the position that "we have no choice but to trust the psychiatrist," "34 and in spite of the creation of special advocacy agencies, ${ }^{35}$ this deference still continues. ${ }^{36}$ The converse is also true. While courtroom mental health professionals rarely complain about being cross-examined in estate or contract cases (where mental health issues are collateral to the controlling issues), they are often indignant when challenged by an attorney representing a patient in the commitment process (where mental health issues are the central issues). ${ }^{37}$ This phenomenon is not a mere coincidence. ${ }^{38}$

\section{A. Role Conflicts and Their Origins}

Any investigation of relevant ethical issues in the commitment process must begin with an examination of (1) the reasons attorneys experience a serious role conflict in representing persons subject to the involuntary civil commitment process, and (2) why attorneys so often find the transition from any other type of legal representation to civil commitment cases so difficult. At least seven different explanations for this role conflict exist.

First, like a majority of the public, many lawyers assume that hospitalization is always beneficial for the mentally handicapped. The lawyers fail to consider the iatrogenic illness often caused by hospitalization, ${ }^{39}$ or of the disabling side effects often caused by the administration of psychotropic medication regularly dispensed to such patients. ${ }^{40}$ Although cases such as Rennie $v$. Klein ${ }^{41}$ have begun to take notice of these disabling effects, they have remained unknown to much of the bar.

Second, the hospital is a closed system ${ }^{42}$ which is impossible to understand without many hours of study and contact. As hospital administrators control virtually all aspects of the system-access, time, conditions of confinement, communications-a power imbalance is created. This power imbalance makes it almost impossible for counsel to deal with his client, to confront witnesses, or to develop proofs.

L. REv. 1, 54-55 (1971), cited in Comment, The Louisiana Mental Health Law of 1977: An Analysis and Critique, 52 TUL. L. REV. 542, 566 (1978).

34. Cohen, supra note 6 , at 450 .

35. See, e.g., N.J. STAT. ANN. \$\$ 52: 27E-21 to 27 (West 1980); S. HERR, supra note 7, at 58-69.

36. See, e.g., Scallet, The Realities of Mental Health Advocacy: State ex rel. Memmel v. Mundy, in Mental Health Advocacy: An Emerging Force in Consumers' Rights 79 (1977); Zander, Civil Commitment in Wisconsin: The Impact of Lessard v. Schmidt, 1976 WIS. L. REv. 503, 555 (court accepted hospital psychiatric testimony in $94 \%$ of sample studied). Contra Tanay, Refections on a Debate, 8 BuLL. AM. ACAD. PSyChIATRy \& L. vii, viii (1980) (Zander study may show that commitment decisions are the "products of careful and thoughtful inquiry').

37. Representing Individuals, supra note 6, at 502; see, e.g., M. PESZKE, Involuntary TREATMENT OF THE MENTALLy ILL (1975).

38. See, e.g., McGarry, Demonstration and Research in Competency for Trial and Mental Illness: Review and Preview, 49 B.U.L. REV. 46 (1969) (characterizing psychiatrists' reluctance to expose themselves to challenge in an arena where final authority is not their own as "professional narcissism').

39. See, e.g., Kantor \& Gellineau, Making Chronic Schizophrenics, 53 MenTAL Hygiene 54 (1969); Yolles, Mental Heallh's Homeostatic State: A New Temilory, 7 INT. J. Psychiatr y 327, 328 (1969). See generally I. Illich, Medical Nemesis: The EXPRopriation of Health (1976).

40. See, e.g., Zander, Prolixin Decanoate: A Review of the Research, 2 Mental Disabilitry L. RPTR. 37,39 (1977).

41. 653 F.2d 836, 843-844 (3d Cir. 1981), vacaled and remanded, 102 S. Ct. 3506 (1982).

42. See, e.g., E. Goffman, Asylums (1961). 
Third, in spite of case $\operatorname{law}^{43}$ and statutes ${ }^{44}$ which forbid a presumption of incompetency because of a person's institutionalization, in any case involving a person perceived as mentally ill, credibility becomes an issue per se. If a lawyer doubts his client's credibility, his perception may have a devastating effect at trial, especially where the issue before the court centers on whether or not the client facing commitment is mentally ill.

Fourth, because of the very nature of total institutionalization, a patient will often find it impossible to bring in coworkers, friends, relatives, neighbors, or character witnesses to testify on his behalf at a commitment hearing. There may be other persons (such as hospital staff members, outside therapists, or other patients) capable of providing favorable testimony for the patient. However, a lawyer must demonstrate a special degree of ingenuity and persistence to track down and interview these witnesses. Without such persistence, the client's representation will not be complete.

Fifth, what a sociologist might characterize as the attorney's "rolelessness" often breeds confusion; contrary to the dictates of case law, both counsel and the courts often perceive commitment proceedings as nonadversarial. ${ }^{45}$ The lawyer's lack of identification with his client often engenders distance between lawyer and client. Also, there is a lack of clearly stated goals. Unlike a typical criminal trial in which a defendant is either found "guilty" or "not guilty," or an ordinary civil case where a cause of action is either found to exist or not to exist, a civil commitment matter does not fit into a discrete paradigm. This void causes ambivalence, as the lawyer may be incapable of perceiving the characteristics of a "victory" or a "loss."

Sixth, many lawyers possess scant knowledge about psychiatric decisionmaking, diagnoses, and evaluation tools. This shortcoming can seriously impede their cross-examination of expert witnesses. ${ }^{46}$ Once psychiatric testimony is elicited few lawyers have the special skills to evaluate such testimony. ${ }^{47}$ Although at least one recent study shows that with respect to sporadically appointed counsel, knowledge of psychiatric techniques may make virtually no difference in case outcomes, ${ }^{48}$ such knowledge must still be viewed as essential for counsel involved in such representation. ${ }^{49}$

43. See, e.g., McAuliffe v. Carlson, 377 F. Supp. 896, 904 (D. Conn. 1974), supp. order 386 F. Supp. 1245 (D. Conn. 1975), supp. order rev'd on other grounds, 520 F.2d 1305 (2d Cir. 1975), cert. denied, 427 U.S. 911 (1976).

44. See, e.g., N.J. STAT. ANN. \$§ 30:24-2c (West 1980).

45. See, e.g., Lessard v. Schmidt, 349 F. Supp. 1078, 1099 (E.D. Wis. 1972), and articles cited therein. Cf. Zander, supra note 36 .

46. Thus, the recent adoption by the American Psychiatric Association of a new Diagnostic and Statistical Manual (DSM III) requires trial attorneys to learn an entirely new system of psychiatric classification based on new diagnostic categories. Compare APA, Diagnostic and Statistical Manual of MENTAL DisOrders (2d ed. 1968) with id. (3d ed. 1980).

47. See, e.g., J. Ziskin, Coping with Psychiatric and Psychological Testimony (3d ed. 1981).

48. Poythress, Psychiatric Expertise in Civil Commitment: Training Attomeys to Cope with Expert Testimony, 2 L. \& HuM. BeHAV. 1 (1978) (study involved sporadically appointed counsel).

49. Poythress concludes, for instance, that "trained" lawyers' courtroom behavior was not materially different from that of "untrained" lawyers because the allegedly "trained" lawyers' attitudes had not changed. Knowledge of cross-examination techniques alone "did not deter them from taking [the] more 
Finally, and perhaps most importantly, many attorneys deal ineffectively with their clients' "differentness." Patients are often passive, frightened, heavily medicated, unable to articulate their wishes forcefully, and unaware of their alternative options. Because a patient's appearance, manner, dress, or speech may be "different," the lawyer may feel somewhat foolish or awkward representing his client's views to the court. This "differentness" may engender embarrassment which will inevitably diminish the scope and quality of the attorney's advocacy. ${ }^{50}$

These role conflicts have been analyzed infrequently. Although several law review articles have alluded to them, ${ }^{51}$ virtually no case law exists on the impact of the presence of such conflicts. Even those comparatively rare decisions which attempt to define the role of adversary counsel in the commitment process ${ }^{52}$ generally limit their discussions to an articulation of the role the lawyer should play ${ }^{53}$ or should not play. ${ }^{54}$ The reasons for the lawyers' ambivalence and role conflicts are almost never the topic of legal analysis.

\section{B. Process Conflicts}

Beyond role issues involving the approach of the individual attorney lurk other ambiguities and conflicts which center on the role of the entire legal process in mental health cases. First, the dispositional phase of a commitment case is ambiguous and almost always open for modification (as a partial reflection of the frequent changes in mental conditions and symptomatology of many persons who are the subjects of commitment proceedings). ${ }^{55}$ This ambiguity is inconsistent with the concept of "finite resolution,"56 a hallmark of legal decisionmaking.

traditional, passive, paternal stance towards the proposed patients." Poythress, supra note 48, at 15 . In the words of one trainee: "I really enjoyed your workshop and I've been reading over your materials and its [sic] all very interesting, but this is the real world and we've got to do something with these people. They're sick." Id.

50. Representing Individuals, supra note 6, at 505. See generally Litwack, The Role of Counsel in Civil Commitment Proceedings: Emerging Problems, 62 CALif. L. REV. 816, 827-31 (1974).

51. See, e.g., Lockwood, How to Represent A Client Facing Civil Commitment, 26 Practical LaWYer 51, 53 (1980); Poythress, Mental Health Expert Testimony: Current Problems, 5 J. Psychiatry \& L. 201, 210-13 (1977); Zander, supra note 36, at 514-17; Note, The Role of Counsel in the Civil Commitment Process: A Theoretical Framework, 84 YALE L.J. 1540, 1560-63 (1975) [hereinafter cited as Yale Note]. See generally Representing Individuals, supra note 6 , at 502-05, and sources cited therein.

52. See, e.g., State ex rel. Memmel v. Mundy, 75 Wis. 2d 276, 283, 249 N.W.2d 573, 576-77 (1977); Quesnell v. State, 83 Wash. 2d 224, 231, 1517 P.2d 568, 575-76 (1974).

53. The Memmel decision stated:

However, with the legislature now specifically requiring the appointment by the court of an "adversary counsel," it should be made clear that such appointed counsel has the same function, duties and responsibilities as he would have if he were retained by the person involved as his or her own attorney. The duties and responsibilities of lawyer to client in this state are set forth in the Code of Professional Responsibility promulgated by this court. They include preserving the confidences and secrets of a client, exercising independent professional judgment on behalf of a client, representing a client competently, and representing a client zealously within the bounds of the law.

75 Wis. $2 \mathrm{~d}$ at 283,249 N.W.2d at 577 (footnotes omitted).

54. Quesnell v. State, 83 Wash. 2d at 233, 517 P.2d at 579 (characterizing passive approach "as a means of supporting procedural aberrations in the mental illness hearing [as] an intolerable abuse of the duty to ensure stringent protection of constitutional and statutory rights").

5. See, e.g., State v. Krol, 68 N.J. 236, 344 A.2d 289 (1975); State v. Fields, 77 N.J. 282, 390 A.2d 574

56. Representing Individuals, supra note 6 , at 505. For an excellent analysis of the special problems raised 
Second, the lawyer's counseling skills are most essential in mental health cases. ${ }^{57}$ Unfortunately, little attention is devoted to teaching these skills, which becomes a particular liability in the commitment process. ${ }^{58}$

Finally, and most importantly, the commitment arena is largely invisible: Courtrooms are usually closed ${ }^{59}$ and dockets merely reflect anonymous initials. ${ }^{60}$ Partially for these reasons, the usual tangible and intangible benefits involved in the successful representation of traditional civil or criminal clients in a courtroom setting-money, prestige, publicity, peer admiration, pride, political recognition, even judicial awareness - are often missing in commitment cases.

The lawyer's personal role conflicts, coupled with process conflicts, create a confused picture for the lawyer representing a putatively mentally disabled person at a commitment hearing.

C. Duties of the Attorney in the Commitment Process and Resolution of Ethical Ambiguities

In the commitment process, the attorney is simply an advocate, serving in a traditional, adversarial, partisan role. He is neither a "friend of the court" nor the representative of the patient's "best interests."61 The definition adopted by the Supreme Court in Anders v. California ${ }^{62}$ - "the constitutional requirement of substantial equality and fair process can only be attained where counsel acts in the role of an active advocate in behalf of his client, as opposed to that of amicus curiae" 63 _ is equally applicable to mental health cases. ${ }^{64}$

Few cases have explicitly discussed whether there are additional role functions for the lawyer in civil commitment proceedings. ${ }^{65}$ In a habeas corpus application challenging the adequacy of counsel in a juvenile delinquency matter, a federal district court in Wisconsin distinguished a typical criminal action from a juvenile proceeding, ${ }^{66}$ noting that " $[t]$ hese differences - the need to investigate an entire life, to devise a plan for a useful future and the maturity of his client-emphasize lawyering qualities which require time to germinate in each case, rather than those qualities which come reflexively to the experienced attorney." 67 This need for

in similar circumstances, see Special Project, The Remedial Process in Institutional Reform Litigation, 78 Colum.

L. REV. 784 (1978).

57. See, e.g., Perlin \& Siggers, supra note 27, at 207-10.

58. See generally A. Watson, The LaWyer in the Interviewing and Counseling Process (1976).

59. See, e.g., N.J. CT. R. 4:74-7(e) (1982).

60. See, e.g., State v. Fields, 77 N.J. 282, 298, 390 A.2d 574, 582 (1978).

61. Representing Individuals, supra note 6 , at 506 .

62. 386 U.S. 739 (1967).

63. Id. at 744 .

64. For an eloquent statement of the traditional view of advocacy, see Freedman, On Advocacy, 1 VILl. L. REv. 290 (1956). For similar formulations, see, e.g., Blinick, Mental Disability, Legal Ethics, and Professional Responsibility, 33 ALB. L. REv. 92, 115 (1968); Andalman \& Chambers, supra note 28, at 48. For a similar formulation from a different perspective, see Halpern, Anticipated Misuse of Psychiatry Under the New York Juvenile Offender Law, 6 Bull. Am. ACAD. Psychiatry \& L. 382, 385, 387 n.17 (1978) (citing AmEr ICAN SOCIETY FOR ADOLescent Psychiatry NewsletTer, Jan. 1975, at 8).

65. See, e.g., State ex rel. Memmel v. Mundy, 75 Wis. 2d 276, 249 N.W.2d 573 (1977); Quesnell v. State, 83 Wash. 2d 224, 517 P.2d 568 (1974).

66. Miller v. Quatsoe, 332 F. Supp. 1269 (E.D. Wis. 1971).

67. Id. at 1275 . 
"lawyering qualities which require time to germinate" has not been addressed, even in those few cases which point out, for example, that the patient's attorney "has a duty to the individual and the legal system to represent his client as zealously as the bounds of ethics permit." 68 Indeed, a leading theoretical commentary simply states, "Once the adversary nature of the lawyer's role is reestablished in commitment proceedings, his role in operational terms resembles that in ordinary cases."'69

The use of the word "operational" begs the point. Although the attorney's approach and perspective should resemble the role in "ordinary cases," this does not mean that, in preparation of such a case, an attorney has no greater responsibilities than in other types of litigation. Indeed, the role conflict problems mandate that the attorney's role in the commitment process carries additional obligations.

A modest body of literature, sketching out the duties of an attorney in a commitment case, ${ }^{70}$ has established predictable guidelines. The attorney must familiarize himself with the facts of the case and learn the client's objectives, interview the client, investigate the case, interview other witnesses, determine the range of available alternatives, advise the client of potential dispositions, negotiate, protect procedural rights, advocate effectively at the hearing, suggest dispositional alternatives, and provide appropriate post-adjudicative representation. ${ }^{71}$ Each of these seemingly routine steps in a commitment hearing, though, is slightly different from its counterpart in the "ordinary case."

Somewhat remarkably, the Michigan State Bar Committee on the Mentally Disabled, the author of an article on civil commitment representation, ${ }^{72}$ did not consider it too obvious to mention that the attorney should learn the facts of the case and ascertain his client's position. The inclusion of this "guideline" is powerful evidence that, operationally, commitment cases are not regularly treated by counsel as "ordinary cases." The previously referred to literature on the inadequacy of representation, ${ }^{73}$ however, demonstrates that this first admonition may not be as self-explanatory as it appears.

Further, the initial interview is usually conducted in alien territory, ${ }^{74}$ a factor which may shape interview content. ${ }^{75}$ Such an interview environment obviously differs from the prototypical lawyer-client office interview (or luncheon meeting).

68. State ex rel. Hawks v. Lazaro, 202 S.E.2d 109, 126 (W. Va. 1974).

69. Yale Note, supra note 51 , at 1562.

70. See, e.g., S. Schwartz \& D. STern, Trial Manual for Civil Commitment (1977), reprinied in 1 Mental Disability L. Rep. 379 (1977). See genetally Singer, Mental Health Law in New Jersey: Theory and Practice (1981); Hagel, Defending the Mentally Ill: A Discussion of Nebraska's Involuntary Commitment Proceedings, 57 NEB. L. REV. 1 (1978); Lockwood, supra note 51; Practice Manual, The Attomey's Role at the Commitment Hearing: Guidelines and Practical Considerations, 2 Mental DiSABILITY L. REP. 427 (1978); Practice Manual, Preparation and Trial of a Civil Commitment Case (Part II), 5 MeNTAL DisabilitT L. REP. 281 (1981) [hereinafter cited as Peparation Part II].

71. See generally Representing Individuals, supra note 6, at 507-11.

72. See Practice Manual, The Altomey's Role at the Commitment Hearing: Guidelines and Practical Considerations, 2 Mental Disability L. Rep. 427 (1978).

73. See rupre text accompanying notes 30-38.

74. Lockwood, supra note 51 , at 54 .

75. See, e.g., E. Gofrman, supra note 42 , at 13. 
Whereas the client in the ordinary case will usually have little difficulty articulating his wishes, the institutionalized patient may be suspicious, terrified, puzzled, or simply distrustful of the attorney.

The investigation of the case also will differ in both scope and approach from "ordinary cases."76 Obviously, the ability to read and understand the medical chart is essential to any investigation. ${ }^{77}$ As an independent psychiatric expert will probably be "the single most valuable person to testify on behalf of a client in a contested commitment hearing," 78 it is critical that the attorney seek such independent assistance. ${ }^{79}$

All attorneys must have the special skills and sensitivity needed to interview witnesses in the preparation of any case. The commitment attorney must interview hospital social service staff, other patients, and the patient's friends, neighbors, and employers about both the facts and circumstances of the hospitalization and the events which preceded it. ${ }^{80}$ Many of the facts adduced from such investigations will involve new discoveries. As a result, they become critical as potentially valuable leverage in seeking a reconsideration of diagnosis.

Of special importance is the attorney's ability to determine the range of alternatives to in-patient hospitalization available to the client: What halfway houses, community mental health centers, or patient-run alternatives are available? What economic benefits and entitlements might the patient receive outside the hospital? Is the alternative program one likely to survive economically in the coming budget cuts? Is the program one specifically suited for persons with the client's condition? Although these are classic social service issues, the lawyer representing the patient must invariably assume the responsibility for answering these questions. Moreover, and more importantly, the court's ultimate determination will turn on the question of whether the individual can "surviv[e] safely in freedom" 81 without any alternative treatment. If the patient can so survive, it is not the lawyer's role to attempt to impose such treatment over his client's objections.

On the other hand, the attorney is obligated to advise the client about all possible dispositions of the case. He must explore in a nonpaternalistic manner whether the client's objectives are realistic (e.g., does he meet threshold eligibility requirements for a certain type of alternative program). If, for instance, the client is not likely to be released-because there is a reasonable expectation that the

76. The lawyer must be highly aware of "hidden agenda" issues. Such hidden agendas-always a possibility in any case-may be more subtle and nefarious in commitment cases. Is the commitment hearing a cover for a divorce matter or a child custody dispute? Is the case simply a "back door" way of dealing with an adolescent with a drug problem or of attempting to avert a marriage unwanted by other family members? A lawyer's "lawyering" instincts must be at their highest level to ferret out such issues within issues. See Representing Individuals, supra note 6, at 514-15.

77. See, e.g., Preparation Part II, supra note 70, at 285-87 (analyzing specific portions of the treatment chart).

78. Id. at 289 .

79. As to the patient's right to such an evaluation, see, e.g., Practice Manual, Areparation and Trial of a Civil Commitment Case (Part I), 5 Mental Disability L. ReP. 201, 208 (1981) [hereinafter cited as Preparation Part I].

80. Preparation Part II, supra note 70 , at $288-89$.

81. O'Connor v. Donaldson, 422 U.S. 563, 575 (1975). 
court will find that there is clear and convincing evidence ${ }^{82}$ that the patient is mentally ill and, as a result of that mental illness, dangerous to himself or others $^{83}$ - the attorney's obligation is to explore with the client all likely outcomes of the hearing. Just as the criminal defense lawyer must explain to the criminal defendant that he may receive a far more lenient sentence if he pleads guilty in lieu of standing trial, ${ }^{84}$ the civil commitment attorney must discuss with his client the option of signing voluntary papers prior to the contested hearing, because such a signing might lead to the imposition of fewer restrictions on the client's liberty than if he contests and is involuntarily committed.

The attorney must, of course, negotiate with hospital staff, the committing authority and/or family members (all of whom may have radically differing views as to appropriate disposition) prior to the court hearing. It has been suggested that "the likelihood of success at this [negotiation] stage is demonstrably greater than at any other"; 85 the experience of New Jersey's Department of the Public Advocate's Division of Mental Health Advocacy in representing tens of thousands of individuals at commitment and periodic review hearings over more than seven years certainly supports this assertion. 86

At the commitment hearing the attorney must protect the full range of the client's procedural rights. In certain situations, motions may be appropriate to challenge the sufficiency of the commitment certificates, ${ }^{87}$ or to challenge the exclusion of the patient from the hearing. ${ }^{88}$ Decisions must be made as to whether the patient should testify on his own behalf (or, increasingly, whether the patient has a right to resist court-directed questioning at such a proceeding) ${ }^{89}$ and whether other witnesses should be produced (a decision often the subject of sharp disagreement between counsel and client). ${ }^{90}$ Even more importantly, the attorney must educate an often poorly informed court in the nuances of commitment law. ${ }^{91}$ While an attorney may assume judicial knowledge of landlord-tenant laws, criminal law or divorce law concepts, such an assumption is often inaccurate in mental health matters generally and commitment cases specifically.

If it is found that the patient meets the statutory commitment standards, the

82. See, e.g., Addington v. Texas, 441 U.S. 418, 443-44 (1979).

83. See, e.g., State v. Krol, 68 N.J. 236, 252-53, 344 A.2d 289, 302 (1975).

84. As to counsel's responsibility in a criminal case, see McMann v. Richardson, 397 U.S. 759, 768-71

(1970); see also Brady v. United States, 397 U.S. 742, 756-57 (1970).

85. Preparation Part II, supra note 70, at 288.

86. See, e.g., Representing Individuals, supra note 6 , at 510 .

87. See, e.g., N.J. Ct. R. 4:74-7(b) (1982) (listing the necessary elements of such certificates).

88. See, e.g., In re Watson, 91 Cal. App. 3d 455, 154 Cal. Rptr. 151 (1979); In re James, 67 Ill. App. 3d 49, 384 N.E.2d 573 (1978).

89. See, e.g., State v. Mathews, 46 Or. App. 757, 613 P.2d 88 (1980), cert. denied, 450 U.S. 1040 (1981); Cramer v. Tyars, 23 Cal. 3d 131, 588 P.2d 793, 151 Cal. Rptr. 653 (1979); Tyars v. Finner, 518 F. Supp. 502 (C.D. Cal. 1981) (holding that a mentally retarded person who is the subject of an involuntary civil commitment proceeding may be called as a witness at such a hearing even though he could not be questioned as to matters which might tend to incriminate him).

90. A client may insist on calling a friend, neighbor or other individual to testify. These wishes should be followed if necessary, but the client should be counselled about the potential adverse reaction of friends and family who must testify at a trial and how reluctance to testify may result in unfavorable testimony.

Preparation Part II, supre note 70, at 295.

91. For an expert witness' perspective on this issue, see generally R. SADOFf, supra note 23. 
attorney has additional responsibilities at the disposition stage to suggest alternatives to inpatient commitment. Because most cases do not fall simply into a finite "commit/don't commit" paradigm, ${ }^{92}$ there is a far greater burden on the attorney to seek dispositional alternatives than in the "ordinary case." While a courtappointed probation officer in the criminal process is specifically charged with finding and monitoring alternatives to incarceration, ${ }^{93}$ such officials are rarely present in the commitment process. The impact of "transitional service" social staff at hospitals on structuring such alternatives has been little studied but the findings of such a study would probably show little impact on the day-to-day functioning of the commitment process. ${ }^{94}$ Individual courts may consider the full range of social, educational, and religious agencies and may find an acceptable alternative to the commitment process. ${ }^{95}$ Such possibilities place a burden on the attorney to search out and study such possible placements for his client, while at the same time avoiding the excesses of what Kittrie has termed "The Therapeutic State."96

Finally, following commitment, the attorney must be available for representation at periodic review hearings and on appeal matters. ${ }^{97}$ In addition, there are other duties, including the monitoring of treatment ${ }^{98}$ (especially with regard to medication), ${ }^{99}$ protection of civil rights and insurance of due process in institutional determinations, ${ }^{100}$ and protection of economic rights. ${ }^{101}$ Although these duties are often viewed as collateral ones, ${ }^{102}$ the lawyer's ethical duties do not necessarily terminate at the time of the commitment disposition.

Beyond the "ordinary" commitment case, special problems arise in matters

92. See supra text accompanying notes 70-84.

93. See, e.g., N.J. STAT. ANN. \$ 2C:45-1 (West 1971).

94. The role of such "transitional service" agencies is before the court in In re S.L., No. A-47 (N.J. App. Div., Feb. 24, 1982), reprinted in 15 Clearinghouse Rev. 381 (1981), cert. granted, N.J. Sup. Ct., May 20,1982 (involving nine consolidated appeals of patients at a state hospital discharged on paper ("pending placement") but kept in the facility because of lack of adequate aftercare alternatives).

95. See generally Perlin, The Deinstitutionalization Myths: Old Wine in New Bolltes, in CONrERENCE Report: The Second National Conference on the Legal Rights of the Mentally Disabled 20, 26-27 (1978).

96. N. KITTRIE, supra note 6 , at 1-4.

97. Appeals of commitment matters are relatively rare for several reasons, including a lack of avaitable counsel, the paucity of legal issues confronted directly below, and the creation of frequently scheduled periodic review hearings in many jurisdictions. Note, though, that the New Jersey State Supreme Court has just amended the court rules to specify that the filing of an appeal from an adverse commitment does not stay pending periodic review proceedings. N.J. CT. R. 4:74-7(f) (1982). See generally PressLER, CURRENT N.J. Court Rules 866 (1982) (Comment to R. 4:74-7).

98. As to the justiciability of treatment matters at commitment hearings, see In re D.J.M., 158 N.J. Super. 497, 386 A.2d 870 (App. Div. 1978).

99. See, e.g., Rogers v. Okin, 634 F.2d 650 (1st Cir. 1980), vacaled and remanded sub nom. Mills v. Rogers, 102 S. Ct. 2442 (1982); Rennie v. Klein, 653 F.2d 836, 845 (3d Cir. 1981), vacaled and remanded, 102 S. Ct. 3506 (1982).

100. See, e.g., Davis v. Balson, 461 F. Supp. 842 (N.D. Ohio 1978).

101. See, e.g., Cospito v. Califano, 89 F.R.D. 374 (D.N.J. 1981); Schindenwolf v. Klein, No. L-4129375 P.W. (N.J. Super. Ct. filed Nov. 17, 1976), consent judgment reported in 5 MENTAL DiSABILITY L. REP. 60 (1981). See generally Perlin, Other Rights in Institutions, in 2 LEGal Rights OF MENTALLY Disabled Persons 1001, 1018-24, 1027-28 (P. Friedman ed. 1979).

102. For a rare analysis, see Golten, Role of Defense Counsel in the Criminal Commitment Process, 10 AM. CRIM. L. REV. 385, 408-09 (1972). 
where the client either cannot or does not express his feelings about possible outcomes. Most commentators suggest that if the patient remains silent the lawyer should assume that the client wishes to fight commitment. ${ }^{103}$ Under any circumstances, the attorney is obligated to question friends, families, and others in an attempt to make a collateral determination of the client's views. ${ }^{104}$ It has been suggested that, in such cases, there should be an always-or-never rule-that counsel should either always oppose commitment or always acquiesce. ${ }^{105}$ Such rigidity seems inappropriate. A collateral investigation should be pursued in each instance. In any event, the ethical dilemma of whether or not to fight commitment significantly distinguishes mental disability cases from "ordinary cases," and should be the subject of more sensitive attention. ${ }^{106}$

Another major issue is the impact of providing counsel for patients subjected to commitment proceedings. Although research studies show that patients do desire representation on a variety of legal matters, ${ }^{107}$ the actual effect of representation on patients has rarely been explored. Although Chief Justice Burger characterized commitment hearings for juveniles as meaningless "time-consuming procedural minuets," 108 most studies unequivocally reject this view, ${ }^{109}$ noting that the commitment process itself has "considerable potential for therapeutic effect."110 The Chief Justice's characterization has not yet had a profound practical impact, 111 but his concern will probably engender further scrutiny of the ethical implications of holding such hearings.

An analysis of the structure of the legal services provided at commitment hearings is important to an understanding of the ethical issues involved in commitment representation. Undisputedly, counsel is best provided through a regularized, organized system of legal service delivery, established in independent offices, staffed with full-time advocates whose sole job it is to provide legal representation to the handicapped. ${ }^{112}$ This model, however, is not followed in many jurisdictions. ${ }^{113}$ Nor has the private bar vigorously taken advocacy initiative. ${ }^{114}$

103. See, e.g., Representing Individuals, supra note 6, at 513 .

104. See generally S. HER R, supra note 7 , at $140-42$

105. See Yale Note, supra note 51 , at $1562-63$ n.84.

106. For a thoughtful analysis, see Mickenberg, supra note 7

107. See, e.g., Epstein \& Lowinger, Do Mental Patients Want Legal Counsel.' A Survey, 45 AM. J. ORTHOPSYCHIATRY 88, 91-92 (1975); see also Brakel, supra note 7, at 469-71.

108. Parham v. J.R., 442 U.S. 584, 606-07 (1979).

109. For a direct response to the Chief Justice, see Perlin, An Invitation to the Dance: An Empirical Response to Chief Justice Warren Burger's 'Time-Consuming Procedural Minuets' Theory in Parham v. J.R., 9 BULL. AM. Acad. Psychiatry \& L. 108 (1981).

110. Ensminger \& Liguori, The Therapeutic Significance of the Civil Commitment Hearing: An Unexplored Potential, 6 J. Psychiatry \& L. 5, 7 (1978); see also Cumming \& Goyer, Therapeutic Consequences of the Involuntary Commitment Process, 1 AM. J. Forens. Psych. 37 (1979). But of. Galie, An Essay on the Civil Commitment Lawyer: Or How I Leamed to Hate the Adversay System, 6 J. Psychlatry \& L. 71, 86 (1978) (questioning "whether the adversary system is the most efficient way to determine who is mentally ill") (emphasis added).

111. Perlin, supra note 109 , at 109 .

112. For a general discussion of the literature, see Van Ness \& Perlin, supra note 6, at 67-68, and articles cited supra notes 26-30. See generally Zander, supra note 36 . For a case analysis, see State ex rel. Memmel v. Mundy, 75 Wis. 2d 276, 249 N.W.2d 573 (1977). On the question of institutional legal services, see Brakel, Schwartz \& Fleischner, Legal Advocacy for Persons Confmed in Mental Hospitals, 5 MENTAL DisABILITY L. REP. 274 (1981).

113. See, e.g., N.J. Stat. AnN. $\$ \S 52: 27$ E-21 to 27 (West 1980) (New Jersey Department of the Public 
With this backdrop, the Task Panel on Legal and Ethical Issues of the President's Commission on Mental Health formulated specific advocacy recommendations:

The panel suggests that the Commission endorse a Federal mechanism or, in the alternative, urge States to develop advocacy systems which are (1) able to respond to the legal needs of mentally disabled persons and (2) independent of providers of mental health and developmental disability services. An essential feature of such advocacy systems should be their effort to provide a continuity of legal services to such persons at all stages of their contact with the mental disability system. Such advocacy systems should provide services at involuntary-commitment proceedings and to institutionalized persons of all ages, as well as to community residents, in matters involving institutionalization (commitment, release, treatment issues), the fact of present or former institutionalization (availability of economic benefits, aftercare, denial of civil rights, employment, education issues), and other matters related to the existence - or perceived existence-of a handicap (domestic relations, contracts, wills, tenancy issues). In addition to attorneys (an "indispensable element in seeking and securing many types of remedies"), the advocacy system should be staffed by persons trained as "mental health professionals" (e.g., social workers and psychologists who provide advocacy services), by lay advocates, and by present and former recipients of mental health services, so as to provide a full-time staff with the necessary academic training and practical experience to provide comprehensive advocacy services for its clientele. ${ }^{115}$

This recommendation was specifically endorsed by the President's Commission which recommended "the establishment of advocacy systems for the representation of mentally disabled individuals,"16 noting that such systems were essential "to protect the rights of all who receive services."117

Although a modified and diluted version of this recommendation was ultimately passed by Congress as part of the Mental Health Systems Act, ${ }^{118}$ it was repealed less than one year after enactment as part of President Reagan's Omnibus Reconciliation Act of 1981.119 New initiatives in the area will not likely come from Washington in the near future. President Reagan expects the private bar to provide necessary legal services to the poor if and when the Legal Services Corporation is reduced; ${ }^{120}$ it is not clear what his expectations are regarding the

Advocate's Division of Mental Health Advocacy); N.Y. Mental Hyg. LAW $\S 29.09$ (McKinney 1978) (New York Mental Health Information Service); OHIO Rev. Code ANN. § 119.85 (West 1980) (Ohio Legal Rights Service for the Mentally Retarded).

114. See, e.g., TASK PANEl RePORTS, supra note 2, at 1371 (recommending that local and state bar associations begin to train members of the private bar and establish lawyer referral panels "so as more effectively and adequately to represent mentally handicapped persons"). But see Herr, The New Clients: Legal Senvices for Mentally Retarded Persons, 31 STAN. L. REV. 553, 572 n. 116 (1979) (recognizing contributions of selected private practitioners in major mental disability litigation).

115. TASK PANel Reports, supra note 2, at 1368.

116. 1 President's Commission on Mental Health, Report 42 (1978).

117. Id. (emphasis added).

118. 42 U.S.C.A. $\$ 9502$ (West 1980). The bill, as passed, authorized the Secretary of Health and Human Services to make grants to projects "to protect and advocate the rights of mentally ill individuals." 42 U.S.C.A. $\S 9502($ a) (1) (West 1980).

119. Pub. L. No. 97-35, § 902(e)(1), 95 Stat. 560 (1981).

120. On March 10, 1981, President Reagan proposed eliminating the Legal Services Corporation. 39 ConG. Q. 466 (1981). After a coalition of judges, lawyers, and American Bar Association officials mounted a nationwide campaign to save the Corporation, see, e.g., id. at 529 , Senate and House conferees agreed to remove the reauthorization question from the omnibus reconciliation bill, id. at 1421 . (This action followed the passage of separate bills which would have reauthorized the Corporation at significantly different funding levels: the House bill (H.R. 3480) called for $\$ 241,000,000$ per year; while the Senate bill (S. 1377 ) mandated $\$ 100,000,000$ annually (compared to a current level of $\$ 321,300,000)$. Id. at $1255(1981)$ ). 
provision of such services for the mentally disabled.

\section{When Incompetency of Counsel Violates Due Process}

Surprisingly, the uniqueness of commitment representation has not generated case law on the degree of attorney incompetence necessary to violate due process.

The traditional test for measuring competency of counsel was whether the trial121 "was a farce, or a mockery of justice."122 Following the Supreme Court's decision in McMann $v$. Richardson, 123 which held that due process contemplates "the effective assistance of competent counsel," 124 however, a majority of the circuits began to rephrase the traditional formulation. ${ }^{125}$ Thus, courts have held that representation "should be within the range of competence expected of attorneys in criminal cases," 126 or that it should reflect "the exercise of the customary skill and knowledge which normally prevails at the time and place," 127 or that it should be "reasonably likely to render and [shall be] rendering reasonably effective assistance," 128 or simply that representation should be "reasonably competent and effective."129

Clearly, all of the new standards are "more demanding" or "more stringent"130 than the "farce or mockery" test which was recently criticized as "increasingly inaccurate" as a "protection actually afford[ing] the rights of the accused." 131 To emphasize this greater stringency, some courts have even created checklists of minimal performance standards. ${ }^{132}$ Only a handful of cases decided under any of these

121. Case law which has developed in this regard should be seen as applicable to the involuntary civil commitment process, in spite of the Supreme Court's decision in Addington v. Texas, 411 U.S. 418 (1979). See infra text accompanying notes 139-50. This proposition is true regardless of whether the commitment proceeding is demonstrated as "civil" or "criminal." As the court noted recently in Tyars v. Finner, $518 \mathrm{~F}$ Supp. 502, 508-09 (C.D. Cal. 1981) (a post-Addington case):

Federal courts have consistently determined that Gault teaches protection against compelled selfincrimination extends to any proceeding, whether labeled "civil" or "criminal," which could result in the deprivation of an individual's liberty. Warren v. Harvey, 472 F. Supp. 1061 (D. Conn. 1979); Ruffer v. Phelps Memorial Hospital, 453 F. Supp. 1062 (S.D.N.Y. 1978); Kanteles v. Wheelock, 439 F. Supp. 505 (D.N.H. 1977); Heryford v. Parker, 396 F. 2d 393 (10th Cir. 1968); and Lessard v. Schmidt, 349 F. Supp. 1078 (E.D. Wis. 1972) vacated and remanded on other grounds at 414 U.S. 473, 94 S. Ct. $713,38 \mathrm{~L}$. Ed. 2d 661 (1974); [on remand, 379 F. Supp. 1376 E.D. Wis. 1974); vacated and remanded at 421 U.S. 957, 95 S. Ct. 1943, 44 L. Ed. 2d 445 (1975); reinstated at 413 F. Supp. 1318 (1976)]. [Lessard was remanded twice by the United States Supreme Court for defects other than its self-incrimination rationale, which was based heavily on Gault.]

122. Gillihan v. Rodriguez, 551 F.2d 1182, 1187 (10th Cir. 1977), cert. denied, 434 U.S. 845 (1977); see also Rickenbacker v. Warden, 550 F.2d 62, 65 (2d Cir. 1976), cert. denied, 434 U.S. 826 (1977).

123. 397 U.S. 759 (1970).

124. Id. at 771 .

125. In federal jurisdictions, the test apparently stems from the decision of Diggs v. Welch, 148 F.2d 667 (D.C. Cir. 1945), cert. denied, 325 U.S. 889 (1945). For an excellent analysis of all circuits, see Dyer v. Crisp, 613 F.2d 275 (10th Cir. 1980), cert. denied, 445 U.S. 945 (1981). The relevant literature is cited in Cooper v. Fitzharris, 586 F.2d 1325, 1329 n.5 (9th Cir. 1978), cert. denied, 440 U.S. 974 (1979).

126. United States v. Bosch, 584 F.2d 1113, 1121 (1st Cir. 1978).

127. Moore v. United States, 432 F.2d 730, 736 (3d Cir. 1970).

128. Beasley v. United States, 491 F.2d 687, 697 (6th Cir. 1974).

129. Cooper v. Fitzharris, 586 F.2d at 1327.

130. Dyer v. Crisp, 615 F.2d at 278.

131. Cooper v. Fitzharris, 586 F.2d at 1329.

132. See, e.g., Coles v. Peyton, 389 F.2d 224, 226 (4th Cir. 1968); United States v. DeCoster, 487 F.2d 1197, 1203-04 (D.C. Cir. 1973). 
criteria, however, have focused on the specific responsibilities of counsel when a criminal defendant's mental responsibility is in question. ${ }^{133}$

Those few reported decisions have stressed that failure to "discuss" or "explore" the insanity defense in the appropriate case is "outside the range of competency expected of [counsel] as a defense attorney in a criminal case involving a very serious charge."134 Especially where the evidence against the defendant was so strong that "the defense of insanity was the only reasonable defense available,"135 or where "the trial was certain to result in a conviction unless an insanity defense prevailed," 136 failure "to explore the one avenue which offered a ray of promise"137 would deprive the defendant of effective assistance of counsel.

Only one litigated case applies these principles to the commitment process. ${ }^{138}$ The record of the bar in providing counsel sadly demonstrates a lack of "reasonably effective" or "reasonably competent" representation. Lawyers who believe that "we have no choice but to trust the psychiatrist,"139 or who disregard their clients' position because "they're sick"140 simply do not meet sixth amendment due process standards. Most likely, the lack of reported cases merely reflects a lack of appellate counsel willing to litigate mental health issues.

Analysis of criminal cases raises an additional question: How appropriate is it to analogize the civil commitment process to the criminal process after the Supreme Court's decision in Addington v. Texas? ${ }^{141}$ Addington held that for purposes of allocating the burden of proof, it is "inappropriate"142 to merely engraft the criminal model onto commitment proceedings. Addington makes clear that since "the possible injury to the individual [of inappropriate confinement] is significantly greater than any possible harm to the state . . . the outcome of a civil commitment proceeding is [thus] of such weight and gravity" as to make the "preponderance of the evidence" standard inappropriate. ${ }^{143}$ On the other hand, because "state power is not exercised in a punitive sense"144 and because "the initial inquiry in a civil commitment proceeding is very different from the central issue in either a delinquency proceeding or a criminal prosecution," 145 the "heavy"146 "beyond a reasonable doubt" standard would similarly be improper. ${ }^{147}$ The court compromised in an attempt to "strike . . . a fair balance between the rights of the individual and the legitimate concerns of the state" 148 and mandated

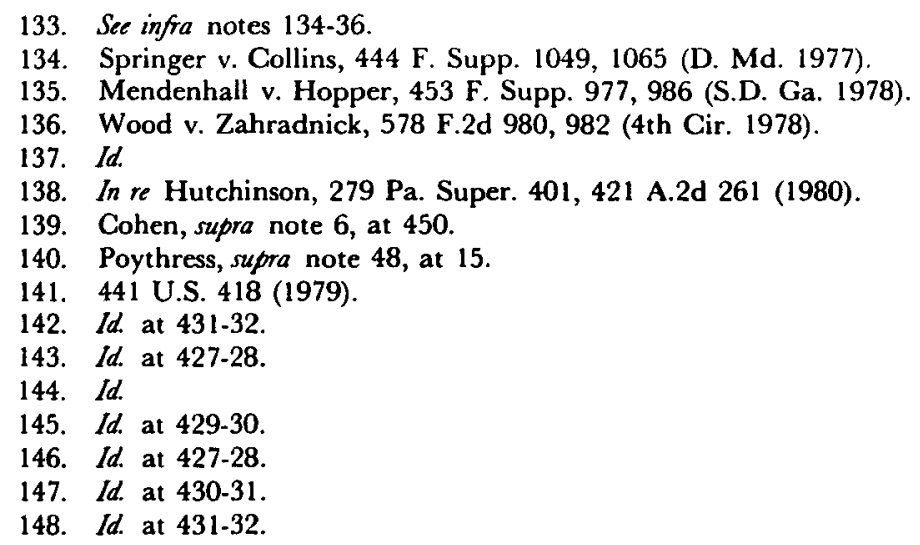


that the evidentiary standard should be "equal to or greater than "clear and convincing'." 149

The Court expressed several concerns in Addington. The Court viewed the civil commitment proceeding as benevolent, specifically rejecting the appellant's assertion "that the release of a genuinely mentally ill person is no worse for the individual than the failure to convict the guilty."150 Also, it acknowledged that if "beyond a reasonable doubt" were to be employed, "the uncertainties of psychiatric diagnosis"151 might impose an insurmountable burden and might "thereby create an unreasonable barrier to needed medical treatment."152

Addington should not diminish reliance on criminal case analogies in competency of counsel analyses. Although the subsequent case of Vitek $v$. Jones ${ }^{153}$ stopped short of mandating counsel in all prison-hospital transfer cases, ${ }^{154}$ other courts have regularly held-for purposes of determining the right to counsel-that sixth amendment considerations apply to the commitment process. ${ }^{155}$ The allocation of the burden of proof in Addington does not render criminal case precedents on the question of effective representation inapplicable. ${ }^{156}$

\section{E. The Bar's View on Ethical Dilemmas in Representing the Mentally Disabled}

The history of the provision of inadequate counsel to the mentally disabled has not inflamed the passions of the nation's judiciary, nor has it resulted in any discernible clarion call by the courts for the provision of vigorous legal advocacy. Although Justice Blackmun pointed out some nine years ago that it was "perhaps remarkable that the substantive constitutional limitations on [the commitment] power have not been more frequently litigated,"157 the subsequent increase in such litigation has not engendered judicial awareness of the ethical issues involved in such representation. Even those cases which have sketched out the appropriate role of counsel ${ }^{158}$ have employed hortatory language, with little consideration of

149. Id. at $433-34$.

150. Id. at 429-30.

151. Id.

152. Id.

153. 445 U.S. 552 (1980).

154. Id. at $1265-67$.

155. See, e.g., Lessard v. Schmidt, 349 F. Supp. 1078, 1097-1100 (E.D. Wis. 1972), vacated on other grounds, 414 U.S. 473 (1973), on remand, 379 F. Supp. 1376 (E.D. Wis. 1974), vacaled and remanded on ocher grounds, 421 U.S. 957 (1975), reinstated, 413 F. Supp. 1318 (E.D. Wis. 1976). Heryford v. Parker, 396 F.2d 393, 396 (10th Cir. 1968).

156. The related criminal/mental health ethical question of whether the insanity defense may be imposed upon a competent criminal defendant over his objection is not within the scope of this article. For analyses of this question, see, e.g., Singer, The Imposition of the Insanity Defense on an Unwilling Defendant, 41 OHIO ST. L.J. 637 (1980); Note, The Right and Responsibility of a Court to Impose the Insanity Defense Over the Defendant's Objection, 65 MinN. L. REv. 927 (1981); see also Perlin, Overview of Rights in the Criminal Process, in 3 Legal Rights of Mentally Disabled Persons 1879, 1896 (P. Friedman ed. 1979). The most important recent cases are State v. Khan, 175 N.J. Super. 72, 417 A.2d 592 (App. Div. 1980), and Frendak v. United States, 408 A.2d 364 (D.C. Ct. App. 1979). For a recent forum on this topic, see Ask the Experts, 7 Newsletter Am. ACAD. Psych. \& L. 28-31 (Aug. 1982).

157. Jackson v. Indiana, 406 U.S. 715,737 (1972).

158. See, e.g., Lessard v. Schmidt, 349 F. Supp. 1078 (E.D. Wis. 1972), vacated on other grounds, 414 U.S. 473 (1973), on remand, 379 F. Supp. 1376 (E.D. Wis. 1974), vacaled and remanded on other grounds, 421 U.S. 957 
the specific ethical dilemmas which frequently surface.

Finally, the American Bar Association (ABA) has begun, belatedly, to consider some of the ethical dilemmas involved in the representation of the mentally disabled. As part of its Commission on Evaluation of Professional Standards' redraft of the Model Rules of Professional Conduct 159_rules drafted to provide "a comprehensive rethinking of the ethical premises and problems of the profession of the law"160_the ABA spoke, specifically, about the lawyer's duty to a "client under a disability." 161 According to the ABA Commission:

Rule 1.14 Client Under a Disability

(a) When a client's ability to make adequately considered decisions in connection with the representation is impaired, whether because of minority, mental disability or for some other reason, the lawyer shall, as far as reasonably possible, maintain a normal clientlawyer relationship with the client.

(b) A lawyer shall secure the appointment of a guardian or other legal representative, or seek a protective order with respect to a client, only when the lawyer reasonably believes that the client cannot adequately communicate or exercise judgment in the client-lawyer relationship. ${ }^{162}$

The Commission notes, in its commentary, that "maintaining the ordinary client-lawyer relationship may not be possible in all respects" when the client "suffers from a mental disorder." 163 Although such a client "may have no authority to make legally binding decisions," he may still have "the ability to understand, deliberate upon and reach conclusions about matters affecting the client's own well-being." 164 The fact of disability "does not diminish the lawyer's obligation to treat the client with attention and respect"; ${ }^{165}$ however, where a legal representative or guardian has been appointed for the client, "the lawyer should look to the representative for decisions on behalf of the client," 166 and, where such a representative has not been appointed, "the lawyer should see to such an appointment where it would serve the client's best interests." 167 On the other hand, if the lawyer represents the guardian and is aware that the guardian "is acting adversely to the ward's interest," the lawyer may have an obligation to prevent or rectify the guardian's misconduct. ${ }^{168}$

The commentary warns, however, that disclosure of the client's disability "can

(1975), reinstaled, 413 F. Supp. 1318 (E.D. Wis. 1976). State ex rel. Hawks v. Lazaro, 202 S.E.2d 109,126 (W. Va. 1974); Quesnell v. State, 83 Wash. 2d 224, 517 P.2d 568 (1974).

159. Model Rules of Professional Conduct (Proposed Final Draft 1981) [hereinafter cited as MODEl Rules].

160. Kutak, Chaiman's Introduction, MODEL RuLEs, supra note 159, at i.

161. MODEL Rules, supra note 159, Rule 1.14.

162. Id.

163. Id. at 94

164. Id.

165. Id.

166. Id.

167. Id. at $94-95$.

168. Id. at 94. The commentary cites, in support of this position, its Draft Rule 1.2(d). That rule states:

(d) A lawyer shall not counsel or assist a client in conduct that the lawyer knows or reasonably should know is criminal or fraudulent, or in the preparation of a written instrument containing terms the lawyer knows or reasonably should know are legally prohibited, but a lawyer may counsel or assist a client in a good faith effort to determine the validity, scope, meaning or application of the law. 
adversely affect the client's interests," potentially leading, for example, "to proceedings for involuntary commitment."169 It characterizes the lawyer's position as "an unavoidably difficult one" and counsels that the lawyer consult "an appropriate diagnostician for guidance" if possible. ${ }^{170}$

The "legal background" to the draft rule refers to the "growing volume of literature concerning the disabled client's rights and counsel's role,"171 citing the relevant scholarship and case law. ${ }^{172}$ It notes the generally inadequate level of representation provided, ${ }^{173}$ and casts the blame, in part, on "the lawyer's ambiguous relationship with the disabled client and . . . uncertainty about the advocate's role in the quasi-adversary proceeding." 174

The lawyer's relationship with a disabled client "ordinarily should not differ from the normal client-lawyer relationship;" 175 the lawyer "is not the client's guardian and is not empowered to substitute his own conception of 'best interest' for that of the client."176 Further, a "disabled client is entitled to reasonable competence, preparation and communication in the representation;"177 although "civil commitment . . . [is] not adversary in the usual sense, the lawyer must perform with appropriate diligence." 178

The commentary notes further that the lawyer, in the course of representation, interacts with third persons "whose interests may conflict with the interests of the disabled client," 179 and warns that "the lawyer's vigor and independent judgment may not be adversely affected by these other interests." 180 Where conflict exists between the client's interests and that of his court-appointed representative, "the lawyer may seek to have that conflict judicially resolved."181 On the other hand, where the client's disability "may prevent effective communication or reliance on the client's judgment," the lawyer should seek the appointment of a legal representative. ${ }^{182}$

Although the draft rule and its accompanying commentary are an important first step toward official recognition of the ethical problems in the representation of

169. Id. at 95 .

170. Id.

171. Id., Legal Background to Rule 1.14, at 95 .

172. Id. at $95-96$.

173. Id. at 96 (citing Andalman \& Chambers, supra note 28); Cohen, supra note 6; Litwack, supra note 50; Mickenberg, supra note 7 .

174. MODEL RULES, supra note 159, Legal Background to Rule 1.14, at 96 (citing Cohen, supra note 6; Litwack, supra note 50; Lockwood, supra note 51; Yale Note, supra note 51). It is not clear from which of these articles the concept of the civil commitment hearing as a "quasi-adversary proceeding" is purportedly developed.

175. MOdel Rules, supra note 159, Legal Background to Rule 1.14, at 96 (citing, inter alia, State ex rel. Memmel v. Mundy, 75 Wis. 2d 276, 249 N.W.2d 573 (1977)).

176. MODEL RULES, supra note 159, Legal Background to Rule 1.14, at 96 (citing, inter alia, Lessard v. Schmidt, 349 F. Supp. 1078 (E.D. Wis. 1972)).

177. MODEl RULes, supra note 159, Legal Background to Rule 1.14, at 97.

178. Id. (citing, inter alia, State ex. rel. Hawks v. Lazaro, 202 S.E.2d 109, 126 (W. Va. 1974)); State ex rel. Memmel v. Mundy.

179. MODEL Rules, supra note 159, Legal Background to Rule 1.14, at 97.

180. Id. But see Parham v. J.R., 442 U.S. 584, 606-07 (1979).

181. Model Rules, supra note 159, Legal Background to Rule 1.14, at 97. See, e.g., In re S.W., 158 N.J. Super. 22, 385 A.2d 315 (App. Div. 1978).

182. MODEL RULES, supra note 159 , Legal Background to Rule 1.14, at 97. 
the mentally disabled, they fall far short of the stated goal that they be "consistent, comprehensive and constitutional."183 First, they are internally inconsistent. They suggest that the lawyer's relationship with a disabled client should not differ from the normal client-lawyer relationship, and then characterize the proceedings in question as "quasi-adversar[ial]," implying a different set of relationships than in the "normal" case. They caution that the lawyer should beware of the third party with conflicting interests (including, specifically, physicians), ${ }^{184}$ but suggest consulting with "an appropriate diagnostician for guidance" on whether to raise the client's disability; the Rules do not consider the possibility that the "physician" and "diagnostician" may be the same person. Although the commentary cites Lessard v. Schmidt ${ }^{185}$ for the proposition that the lawyer cannot "substitute his own conception of 'best interest' "for that of his client, the commentary concedes that the lawyer should "see to" the appointment of a guardian ad litem "where it would serve the client's best interests." 186

Second, the rule is not comprehensive. It ignores some of the most serious ethical dilemmas facing counsel representing mentally handicapped persons, including the patient's refusal of psychotropic medication, ${ }^{187}$ imposition of the insanity defense over a competent defendant's objections, ${ }^{188}$ and the right of a patient to control his own funds. ${ }^{189}$

Finally, the rule may not be constitutional if it views the civil commitment proceeding as "quasi-adversar[ial]." Notwithstanding the Supreme Court's decision in Addington v. Texas, ${ }^{190}$ persons facing involuntary civil commitment-and the concomitant loss of liberty'191 - have a right to the same "traditional, adversarial, partisan" counsel that "is the hallmark of the American judicial system."192 To suggest that they have less implies that the Bar Commission, in spite of its lofty aims, fails to seriously consider the problems faced by mentally disabled persons in the legal system.

The draft rule has not received extensive commentary. An analysis by the legal consultant to the ABA Commission on Evaluation of Professional Standards merely notes that "the normal relationship with a competent client is not necessarily the same as a normal relationship with a disabled client,"193 that the disabled client "creates special burdens for the lawyer,"194 and, thus, that "the lawyer

183. Kutak, supra note 160 , at vi.

184. MODEL RULES, supra note 159, Legal Background to Rule 1.14, at 97.

185. 349 F. Supp. 1078 (E.D. Wis. 1972), vacated on ather grounds, 414 U.S. 473 (1974), on remand, 379 F. Supp. 1376 (E.D. Wis. 1974), vacaled and remanded on other grounds, 421 U.S. 957 (1975), reinstated, 413 F. Supp. 1318 (E.D. Wis. 1976).

186. MODEL Rules, supra note 159 , comment to Rule 1.14, at 94-95.

187. See, e.g., Rennie v. Klein, 653 F.2d 836 (3d Cir. 1981), vacaled and remanded, 102 S. Ct. 3506 (1982).

188. See, e.g., State v. Khan, 175 N.J. Super. 72, 417 A.2d 592 (App. Div. 1980).

189. See, e.g., Vecchione v. Wohlgemuth, 377 F. Supp. 1361,1369 (E.D. Pa. 1974), further proceedings, 426 F. Supp. 1297 (E.D. Pa. 1977), affd, 558 F.2d 150 (3d Cir. 1977), cert. denied, 434 U.S. 943 (1977).

190. 441 U.S. 418 (1979).

191. See, e.g., O'Connor v. Donaldson, 422 U.S. 563, 575 (1975).

192. Representing Individuals, supra note 6, at 506.

193. Patterson, An Analysis of the Proposed Model Rules of Professional Conduct, 31 MERCER L. REV. 645, 659 (1980).

194. Id. at 660 . 
has greater discretion in the representation of these clients than he has in the representation of normal clients."195 The extent of this "discretion" is not elucidated, nor is the type of discrimination necessary to differentiate between a "normal" client and any other ("abnormal"?) client explained. It is hoped that further analyses will probe the full implications of the draft rule.

\section{III}

\section{THE DOCTOR'S VIEW}

In addition to ethical issues which directly affect the lawyer's role, there are other equally important ethical matters for the psychiatrist working with the lawyer representing a patient in the commitment process. These include at least one structural issue - the significance of philosophical and professional orientation differences between the psychiatrist and the mental health advocate-and two substantive ones: The issue of agency (whom does the psychiatrist really represent?) and the multiple aspects of the doctor-patient relationship also relevant to the commitment process, including confidentiality, privileged communications, and informed consent.

The basic function of a psychiatrist treating a mentally ill individual is to attend to the medical needs of the patient. ${ }^{196}$ The psychiatrist functions as the agent of the patient in order to provide the best medical-psychiatric care and treatment available. In this regard, he must be more concerned with perceived medical needs of the patient than with the patient's wishes or desires. If the patient desires treatment different from what the psychiatrist believes is in his best medical interest, the psychiatrist may face the ethical conflict of either providing quality medical care against the wishes of his patient, or giving what he believes is inadequate medical treatment consistent with the wishes of his patient. ${ }^{197}$

The attorney representing the wishes of the patient, by contrast, does not focus upon the patient's medical needs but upon his client's expressed wishes. ${ }^{198}$ When the client's wishes are contrary to the psychiatrist's opinion about the medical needs of the patient, a conflict develops which may require judicial resolution. The judge, or his designee, must decide what is appropriate, ${ }^{199}$ considering both the patient's medical needs and his expressed wishes.

The psychiatrist, in reaching his opinion about commitment of the patient, must consider the patient's diagnosis, his prognosis, his degree of competency in

195. Id.

196. Statement of Ethics for Psychiatrists, 130 AM. J. Psychiatry 1061 (1973).

197. Id. $\$ 6$, at 1062 .

198. See supra text accompanying notes 61-64. The lawyer's denomination of the person at risk as a "client" and the doctor's characterization of him as a "patient" are not merely semantic differences, but tend to put the entire picture into a more appropriate perspective.

199. Federal Judge David Bazelon has characterized the court's role:

No judge would claim the ability to prescribe a particular therapy for a "chronic undifferentiated schizophrenic." But neither would any judge allocate [broadcasting] frequencies to avoid [radio] interference. That is not his task in either case; his role rather is to determine whether a capable expert has studied the problem fully and reached a defensible result.

Bazelon, Implementing the Right to Treatment, 36 U. CHI. L. REV. 742, 745 (1969); see also Bazelon, Psychiatrists and the Adversany Process, ScIENTIFIC AM., June 1974, at 18, 23. 
making decisions about his treatment, ${ }^{200}$ and his degree of "dangerousness."201 Each of these concepts is poorly defined and psychiatric evaluation of them is markedly unreliable. ${ }^{202}$ The diagnosis given is a label which reflects a collection of symptoms, observations and experience on the part of the diagnosing psychiatrist. ${ }^{203}$ Psychiatrists differ in their diagnoses of patients depending upon their own professional orientation, background, education, experience, and age. ${ }^{204}$ Generally, the more severe the symptoms and the more extreme the illness, the more consistent and reliable will be the diagnosis. ${ }^{205}$ However, diagnoses vary even among experienced and skillful psychiatrists depending upon their frames of reference. ${ }^{206}$ Since diagnosis implies prognosis and form of treatment, ${ }^{207}$ the unreliability of the diagnosis naturally leads to a similar unreliability in prognosis and in the recommendations for treatment.

The concept of "dangerousness" is even more vague than is mental illness. "Dangerousness" is not a medical concept but a legal one, ${ }^{208}$ and involves a prediction regarding future violent behavior, either to one's self or to others. Many researchers have concluded that psychiatrists are poor predictors of dangerousness. ${ }^{209}$ The prediction of dangerousness by psychiatrists is, in fact, often linked to the type of mental illness, the degree of its severity, and to the type, extent, and place of treatment. ${ }^{210}$

In the assessment of dangerousness, psychiatrists traditionally consider: (1) any history of previous violent or suicidal behavior;'11 (2) observable factors such as depression, agitation, anxiety, presence or absence of delusions and/or hallucina-

200. See, e.g., Rennie v. Klein, 653 F.2d 836, 846 n.12 (3d Cir. 1981), vacaled and remanded, 102 S. Ct. 3506 (1982).

201. For a full discussion of the different meanings of "dangerousness," see, e.g., State v. Krol, 68 N.J. 236, 259-62, 344 A.2d 289, 296-98 (1975).

202. See, e.g., Ash, The Reliability of Psychiatric Diagnosis, 44 J. ABnORMAL Soc. PsycholoGy 272 (1949) (agreement on diagnosis ranged from 45\%-60\%); Spitzer, Quantification of Agreement in Psychiatric Diagnosis, 17 ARch. Gen. Psychiatry 83 (1967); Beck, Reliability of Psychiatric Diagnoses, 19 AM. J. PsychIATRY 351 (1962) (agreement even lower [54\%] among experienced psychiatrists).

203. For the stigmatization of labeling, see, e.g., Addington v. Texas, 441 U.S. 418, 425-26 (1979); Vitek v. Jones, 445 U.S. at 492 (1980).

204. See Ash, supra note 202; Beck, supra note 202; see also OsKaMPS, PsYCHOL. MONOGRAPHS No. 28 (1982).

205. This conclusion is well-accepted clinically but is not totally accurate. The reliability is based primarily on the extreme symptoms which are accepted as a basis for the definition of the illness. See generally 1 American HandboOK of Psychiatry, Part 6 (S. Aristi 2d ed. 1974).

206. The variance is due primarily to the differences in training and theoretical points of view. A psychiatrist trained in organic pathology will view diagnosis and mental illness differently from one trained in psychodynamic theory and psychoanalysis. However, areas of overlaps will remain especially in extreme cases. See genetally J. Ziskin, supre note 47, at 251-89.

207. Psychiatrists frequently base a decision as to method of treatment on the patient's diagnosis. Methods include use of medication, psychotherapy, type of interaction, frequency of visits, and estimated length of treatment. Prognosis, of course, depends on the patient's response to the treatment given, as well as the diagnosis.

208. See State v. Krol, 68 N.J. 236, 344 A.2d 289 (1975); Sadoff, Indications for Involuntary Hospitalization: Dangerousness of Mental Illness?, in LaW and the Mental Health Professions 297 (1978).

209. See H. Steadman \& J. Cocozza, Careers of the Criminally Insane (1974); J. Monahan, The Clinical Prediction of Violent Behavior (1981).

210. See J. Monahan, supra note 209, at 77.

211. Id. at 71 . 
tions, and behavior of the patient with the examiner; ${ }^{212}$ and (3) psychiatric conclusions based on history and interviews, including such factors as impulse, control, hostility to self or others, degree of insight, judgment, ability to express anger, and means of expressing violent behavior. ${ }^{213}$ A person, for instance, may be considered dangerous at home or in the community, but his illness and his behavior may be well-controlled if he is given adequate treatment in a highly structured environment with proper monitoring of his daily activities. ${ }^{214}$

The degree of competency necessary for a patient to help structure his own treatment-including the threshold question of whether he should be hospitalized, or whether he should receive various types of medication-has not been adequately defined in the law. ${ }^{215}$ Some psychiatrists became concerned about competency when courts began to uphold the rights of involuntarily committed patients to refuse medical treatment. ${ }^{216}$ The courts declared varying standards of refusal, based to some extent on the competency of the patient, i.e., a refusal could not be based on the patient's delusional system or could not be a direct result and/or influence of his illness. Rather, his refusal, to be competent, must be rationally based. ${ }^{217}$ Similarly, in commitment proceedings, the patient may be competent to challenge a hospitalization decision, even though the examining psychiatrist determines that the patient is potentially dangerous. ${ }^{218}$

Unlike dangerousness, competency is rarely assessed in commitment proceedings. ${ }^{219}$ The court may decide upon the commitment of a person for a limited period of time on the basis of his mental illness and dangerousness, but not because of incompetency. In virtually all jurisdictions in the United States, commitment is

212. Id. at 101

213. Id. at 91 .

214. See, e.g., State v. Krol, 68 N.J. at 260, 344 A.2d at 302: "A defendant may be dangerous in only certain types of situations or in connection with relationships with certain individuals. An evaluation of dangerousness in such cases must take into account the likelihood that defendant will be exposed to such situations or come into contact with such individuals"; see also State v. Johnson, 8 Or. App. 263, 493 P.2d 1386 (1972) (defendant potentially dangerous to her children but unlikely to have access to them). See generally State v. Fields, 77 N.J. 282, 302-07, 390 A.2d 574, 596-600 (1978).

215. Although state-level "Patients' Bill of Rights" often stipulate, for example, that "every patient shall have the right to participate in planning for his own treatment to the extent that his condition permits," N.J. STAT. ANN. § 30:4-24.1 (West 1980), the question of the influence of the patient's condition on his participation in the planning process has not been litigated. Similarly, while cases like Rennie v. Klein, 653 F.2d 836 (3d Cir. 1981), vacaled and remanded, 102 S. Ct. 3506 (1982), and Rogers v. Okin, 634 F.2d 650 (1st Cir. 1980), vacated and remanded sub nom. Mills v. Rogers, 102 S. Ct. 2442 (1982), discuss the question of competency and medication refusal, the issue is not one which has been frequently decided. For a recent psychiatric view of this issue, see Roth, Competency to Consent to or Refuse Treatment, in AMERICAN Psychiatric Association Annual Review-1982 (Grinspoon ed.) On the specific question of a patient's capacity to consent to hospitalization, see Appelbaum, Mirkin, \& Bateman, An Empirical Assessment of Competency to Consent to Psychiatric Hospitalization, 138 AM. J. PsychIATRY 1170 (1981) [hereinafter cited as Appelbaum].

216. It should be emphasized that cases such as Rennie are limited to the refusal of antipsychotic drugs. See 653 F.2d at 839 n.2.

217. The impact of competency on refusal decisions is best articulated in Rennie v. Klein, $462 \mathrm{~F}$. Supp. 1131, 1194 (D.N.J. 1978), supp. order 476 F. Supp. 1294 (D.N.J. 1979), modified, 653 F.2d 836 (3d Cir. 1981), vacated and remanded, 102 S. Ct. 3506 (1982); see also Rogers v. Okin, 634 F.2d, 650, 660-61 (1st Cir. 1980), vacaled and remanded sub nom. Mills v. Rogers, 102 S. Ct. 2442 (1982).

218. See, e.g., In re R.B., 158 N.J. Super. 542, 386 A.2d 893 (App. Div. 1978); In re R.N., 170 N.J. Super. 394, 406 A.2d 973 (App. Div. 1979).

219. Compare, e.g., N.J. Ct. R. 4:74-7 (1982) (commitment) with N. J. Ct. R. 4:83 (1982) (guardianship). 
not equated with incompetency. The committed patient retains all civil rights except liberty for a specific period of time. ${ }^{220}$

The involuntary commitment of a patient leads to another question: Does the involuntary commitment order imply that the court has implicitly found that the patient is incompetent to choose his place of treatment?221 While incompetency is generally not specifically adjudicated at commitment hearings, in at least one jurisdiction, Utah, ${ }^{222}$ commitment is impermissible without a preexisting finding of incompetency. ${ }^{223}$ To many treating psychiatrists, the Utah approach is reasonable because it deals with one of the most critical legal-medical issues arising during hospitalization: The extent of the state's power to medicate a patient against his will. The Utah approach is supported by decisions such as Rennie which hold, unequivocally, that the right to refuse treatment is protected by both liberty interests and the requirement of least restrictive alternative. ${ }^{224}$ Such holdings may raise further ethical dilemmas for the treating psychiatrist. ${ }^{225}$

A second major concern for the psychiatrist in commitment proceedings is the notion of agency: whom does the psychiatrist represent and to whom does he owe his loyalties when he examines a client, defendant or patient?226 Generally, the psychiatrist represents the interest of the patient no matter who has asked him to conduct the examination. If he is called as an examining psychiatrist by the patient, then his allegiance is clearly to the patient and his duty is to consider the patient's condition carefully and recommend optimal treatment. Although the psychiatrist is primarily concerned with the patient's best medical interests, he remains an agent of the patient's attorney. "[T]he effective assistance of counsel .. . demands recognition that a defendant be as free to communicate with a psychiatric expert as with the attorney he is assisting."227

A court-appointed psychiatrist has a similar function. Though he acts for the court, his allegiance is to the patient and his perception of the patient's best medical interests. He must, of course, explain to the patient at the time of the examination that he is appointed by the court to conduct the examination and that he will report his findings to the court. If the psychiatrist is a hospital-affiliated psy-

220. Sec, e.g., N.J. STat. ANN. § 30:4-24.2c (West 1980) ("No patient may be presumed to be incompetent because he has been examined or treated for mental illness, regardless of whether such evaluation or treatment was voluntarily or involuntarily received"); McAuliffe v. Carlson, 377 F. Supp. 896, 904 (D. Conn. 1974).

221. See, e.g., Roth, supra note 215 (contrasting de jure and de facto commitments); see also Roth, $A$ Commitment Law for Patients, Doctors and Lawyers, 136 AM. J. Psych. 1121 (1979).

222. UTAH Code ANN. \$67-7-36(10)(c) (West 1980).

223. This statute has been construed in A.E. v. Mitchell, No. C 78-466 (D. Utah 1980). The court held that the plaintiff's right to refuse treatment could be overridden, in part, because of this statutory incompetency finding. For a psychiatric analysis of the case, see Lebegue \& Clark, Incompetence to Refiuse Treatment: A Necessary Condition for Civil Commitment, 138 AM. J. Psychiatry 1075 (1981).

224. 653 F.2d 836, 843-48 (3d Cir. 1981).

225. However, the patient who is adjudicated incompetent at the time of his commitment may, upon receiving adequate treatment in the hospital, improve his mental condition and regain his competency to decide what treatment he wishes shortly after admission. See, e.g., Roth, Meisel \& Lidz, Tests of Competency to Consent 10 Treatment, 134 AM. J. Psychiatry 279 (1977).

226. For an excellent analysis of the "dual loyalty" issue, see Shestack, Psychiatry and the Dilemmas of Dual Loyalties, in Medical, Moral and Legal Issues in Mental Health Care 7 (F. Ayd ed. 1974).

227. United States v. Alvarez, 519 F.2d 1036, 1046 (3d Cir. 1975). 
chiatrist, his allegiance is still primarily to the patient, and he must focus his concern on his perception of the patient's medical interest rather than the patient's wishes. He may recommend hospitalization even over the protest of the patient whom he has examined.

The hospital-affiliated psychiatrist, however, faces different ethical questions than does the neutral, appointed psychiatrist. The former may be the treating psychiatrist who has recommended recommitment, or the psychiatrist who examined the patient during a brief period of emergency commitment to the hospital and recommended a longer period of commitment. He may, in fact, be required to treat the patient in the hospital if the judge commits the patient. This psychiatrist must then be in a position to testify against the patient whom he will subsequently treat. This situation poses a difficult problem for some treating psychiatrists who have not properly prepared their patients for testifying nor convinced the patients of the sincerity of their concern for the patients' medical needs. Some complain that the commitment proceedings in these cases pit the patient against his doctor in an antitherapeutic manner. ${ }^{228}$

Another potential ethical concern of the hospital-affiliated psychiatrist is the legal and ethical conflict of interest inherent in recommending commitment in a hospital where the psychiatrist stands to profit from the commitment. These conflicts arise primarily in private psychiatric hospitals, but may also arise in state hospitals where psychiatrists may recommend extended commitment to continue with research projects that include the patient at risk. Obviously, no patient should be involuntarily maintained in a hospital because he serves as a subject in a research project. In any event, the judge and the patient's attorney must explore the ulterior motives of hospital-affiliated psychiatrists recommending commitment. If a hospital-affiliated psychiatrist has a conflict of interest, he should disqualify himself from the hearing. Instead, a neutral psychiatrist should testify primarily on the medical facts of the case about retention or recommitment to the hospital. ${ }^{229}$

The psychiatrist called by the patient's attorney may face an ethical dilemma. The psychiatrist's legal allegiance is to the patient's attorney, who is presumably looking for a psychiatric opinion that would support the wishes of his client. ${ }^{230}$ Even in this situation, the psychiatrist must evaluate the best medical interests of the patient and render an honest opinion to the attorney. ${ }^{231}$ The advocate must represent the desires of the patient, but the psychiatrist must remain cognizant of the medical needs of the patient despite the circumstances of his entry into the case. He retains an ethical responsibility to assess properly the medical and psychi-

228. Whether this is, in fact, antitherapeutic, is open to debate. See, e.g., Perlin, supra note 109.

229. A neutral psychiatrist who has no interest in the outcome of the hearing should be appointed by the court in order to have available all data and records, to be as objective as possible, and, most importantly, to give the patient a feeling of confidence that the assessment is conducted by an independent psychiatrist in no way connected with or appointed by the hospital.

230. See United States v. Alvarez, 519 F.2d 1036 (3rd Cir. 1975). On the other hand, lawyers seek expert psychiatric opinions for many reasons. See generally Perlin, supra note 19.

231. This, of course, presumes that the question sought to be answered is one relevant to the issue of "medical interests." An assessment of need of medication may be very different from one dealing with competency to stand trial. See, e.g., Drope v. Missouri, 420 U.S. 162 (1975). 
atric problems and, where appropriate, recommend optimal treatment. If his assessment of the patient does not coincide with the needs of the patient's attorney, that attorney has the option of not calling that particular psychiatrist to the hearing. He also has the option of bringing in a second (or tenth) opinion that may more closely coincide with his professional needs, i.e., the wishes of his client.

What is the position of the psychiatrist who renders an opinion which is different from the opinions of the two or ten psychiatrists who have previously recommended hospitalization? The second, fifth, tenth, or twentieth psychiatrist called by the attorney may ethically formulate an opinion that differs from that of his colleagues and may present this opinion in court. However, he should be aware of the conclusions and opinions of his predecessors and the data on which they based their opinions. This psychiatrist must also document the sources of his data and be able to defend his opinion when challenged in court.

Regardless of who calls the psychiatrist for consultation and assessment, the psychiatrist who has any conflict of interest should absent himself from the commitment proceedings. For example, if the hospital wishes to discharge a patient or transfer him to another hospital because his insurance coverage has expired, but the treating psychiatrist recognizes that his therapeutic relationship with the patient is essential to the patient's continued improvement, the psychiatrist has a clear conflict of interest if he recommends transfer or discharge. The conflict is heightened if the transfer facilities are inferior to the private hospital facilities where the patient is currently receiving treatment. A conflict also arises if the treating psychiatrist would profit from a recommendation that the patient remain in the private hospital. If necessary the psychiatrist should explain his situation under oath. The court must then make appropriate fact-findings and legal conclusions. If the judge ultimately rules on the patient's case, the conflict is removed and both the patient and the psychiatrist will have received benefits from the proceeding.

Although psychiatrists often complain about the number and extent of judicial proceedings involving commitment and treatment decisions, the court's involvement tends to protect the psychiatrist in conflict cases. Psychiatric decisions to release or retain a patient sometimes form the basis of negligence suits alleging premature release. ${ }^{232}$ When courts, rather than psychiatrists, decide release questions, the doctor is partially insulated from the potential adverse effects of such litigation. ${ }^{233}$

Before a psychiatrist examines a patient at the request of another party, including the judge, the hospital, or attorneys not representing the patient, the psychiatrist must inform the patient who he is, whom he represents, and what he

232. For the classic case, see Tarasoff v. Board of Regents of Univ. of Cal., 17 Cal. 3d 425, 551 P.2d 334, 131 Cal. Rptr. 14 (1976); see also McIntosh v. Milano, 168 N.J. Super. 466, 403 A.2d 500 (Law Div. 1979). Note, however, that the Tarasoff/McIntosh line of cases has not received unanimous approval in the courts. See, e.g., Case v. United States, 523 F. Supp. 317 (S.D. Ohio 1981).

233. This, however, raises another troubling question: Will this reliance on the courts to "take the weight" for release decisions cause patients to languish in hospitals for inappropriately long time periods when, for instance, there are long gaps between court dates? This issue has been the object of almost no judicial or academic attention. 
will do with the information he receives from the interview and examination. In addition, the psychiatrist must disclose to the patient the potential harm which may flow from the examination. Where a court-appointed psychiatrist was asked to determine the competence of a defendant at a pretrial hearing in a capital case, and was then called as a witness by the state at a post-conviction "death penalty" hearing to testify about the defendant's dangerousness, the testimony was ruled inadmissible as a violation of both the defendant's fifth amendment privilege against self-incrimination and his sixth amendment right to counsel. ${ }^{234}$ The Supreme Court noted:

The fact that respondent's statements were uttered in the context of a psychiatric examination does not automatically remove them from the reach of the Fifth Amendment

The state trial judge, sua sponte, ordered a psychiatric evaluation of respondent for the limited, neutral purpose of determining his competency to stand trial, but the results of that inquiry were used by the State for a much broader objective that was plainly adverse to respondent. Consequently, the interview with Dr. Grigson [the psychiatrist] cannot be characterized as a routine competency examination restricted to ensuring that respondent understood the charges against him and was capable of assisting in his defense. Indeed, if the application of Dr. Grigson's findings had been confined to serving that function, no Fifth Amendment issue would have arisen. ${ }^{235}$

The ethical considerations implicit in the commitment process in this case are clear: A psychiatrist must inform the person he is examining that (1) he is a psychiatrist, (2) he is performing an evaluation for possible commitment to the hospital (i.e., a restriction on his liberty), and (3) what the patient tells him may be used in support of commitment. Unless the examining psychiatrist discloses this information to the patient at the time of the examination, he is not acting ethically. He is depriving the patient of the opportunity to refuse to provide information which might be used in support of an application for commitment.

The examining psychiatrist must be cognizant of numerous ethical considerations, including the duty to preserve the confidentiality of the doctor-patient relationship. In essence, the psychiatrist must not reveal what is entrusted to him in the course of his treatment of the patient. ${ }^{236}$ However, in many cases involving assessment of patients for commitment to hospitals, no traditional doctor-patient relationship is ever established. The doctor does not treat the patient; rather, he assesses him for potential commitment to the hospital. Strict confidentiality cannot be preserved in this situation because the psychiatrist must ultimately present his findings in court so that the judge may make a proper determination and disposition. ${ }^{237}$ Therefore, the psychiatrist must explain to the patient that there is no doctor-patient relationship in this particular setting, and there should be no expectation of secrecy or confidentiality. The psychiatrist does promise that

234. Estelle v. Smith, 451 U.S. 454, 466-69 (1981).

235. Id. at 465 .

236. See Statement on Ethics for Psychiatrists, supra note 196, §9, at 1063 :

A physician may not reveal the confidences entrusted to him in the course of medical attendance, or the deficiencies he may observe in the character of patients, unless he is required to do so by law or unless it becomes necessary in order to protect the welfare of the individual or of the community.

237. Of course, many confidentiality statutes include exceptions to cover precisely this type of situation. See, e.g., N.J. STAT. ANN. § 30:4-24.3(3) (West 1980) (a court may direct disclosure if it "is necessary for the conduct of proceedings before it"). See generally N.J. CT. R. 4:74-7 (1982). 
he will not divulge inappropriately (or to persons not having a direct involvement in the commitment proceeding) any of the material that he has learned.

Privileged communications, which are generally protected by statute or court rule, ${ }^{238}$ also apply to the sanctity of the doctor-patient relationship. ${ }^{239}$ In the course of the assessment for commitment, there is no privilege; i.e., the psychiatrist may testify in court even if the examinee protests and states that he refuses to "give permission" for the psychiatrist to testify before the judge. ${ }^{240}$

Similarly, the examining psychiatrist does not need the informed consent of the patient before testifying. However, he must tell the examinee who he is, whom he represents, and what he will do with the information he receives. ${ }^{241}$ The patient must have the opportunity to refuse to speak to the psychiatrist. ${ }^{242}$ If the court orders the patient to speak to the psychiatrist, then the patient must comply; however, absent such an order or mandate, the patient is free to refuse to discuss his medical condition. On the other hand, if the court deems the situation an emergency, in certain jurisdictions the patient may be committed against his will without a full psychiatric assessment. ${ }^{243}$

For the patient to give effective consent after receiving proper information about the examination, he must be competent to receive the information and to make a decision about cooperating. Basically, if the patient is competent to make decisions about his treatment, then he should be given every opportunity to do so by the psychiatrist, as well as by the court.

Another ethical dilemma arises if the psychiatrist encourages the patient to divulge information to him. If the psychiatrist is also the treater and encourages the patient to tell him "everything that is on your mind," what are the psychiatrist's responsibilities if he is told self-incriminating information? If his patient divulges that he has killed two people, does the psychiatrist have an ethical or legal duty to inform the police? ${ }^{244}$ Attitudes vary; in some cases, the psychiatrist may

238. See, e.g., N.J. R. Evid. 26A-2; N.J. STAT. ANN. §§ 2A:84A-22.1 to 22.9 (physician-patient privilege); N.J. STAT. ANN. $§ \S 45: 14 B-28$ (psychologist-client privilege).

239. Thus, under N.J. STAT. ANN. § 2A:84-22.1(a), "'patient' means a person who, for the sole purpose of securing preventive, palliative or curative treatment, or a diagnosis preliminary to such treatment, of his physical or mental condition, consults a physician, or submits to an examination by a physician."

240. Generally, there is no privilege (since there is no doctor-patient relationship), except in the case of the treating psychiatrist testifying in court to have his patient committed. See United States v. Alvarez, 519 F.2d 1036 (3rd Cir. 1975). The trial court forced the psychiatrist to testify against a defendant whom he had examined at the request of defense counsel. The third circuit held that this compulsion violated the defendant's sixth amendment rights to effective assistance of counsel. Id. at 1045-47.

241. See Statement of Ethics for Psychiatrists, supra note 196, §1, at 1061.

242. The patient may be advised by his attorney not to cooperate with a particular psychiatrist if the attorney believes that decision to be in his client's best interest. The legal strategies are of no concern to the examining psychiatrist; he is under no legal or ethical obligation to "get the information" or conduct the examination.

On the other hand, if a criminal defendant chooses to plead not guilty by reason of insanity, the general rule is that he cannot refuse to speak to a state-appointed psychiatrist on that issue. See, e.g., State v. Whitlow, 45 N.J. 3, 11, 210 A.2d 763, 774 (1965).

243. See, e.g., 50 PA. Stat. ANN. $\$ 7502$ (West 1979).

244. The typical privilege statute is silent on this issue. The New Jersey law, for instance, lists only the following exceptions:

There is no privilege under this act as to any relevant communication between the patient and his physician (a) upon an issue of the patient's condition in an action to commit him or otherwise place 
decide to call the police if, after discussing the matter with the patient, he believes the patient is telling the truth. The psychiatrist should encourage the patient to tell the police himself, and perhaps should offer to accompany the patient to the police station. For lesser criminal matters, such actions might not be appropriate. ${ }^{245}$

With respect to commitment, however, the psychiatrist may use criminal information supplied by the patient to evaluate his dangerousness. Certainly, if the patient discloses a plan to harm someone or to engage in other criminal behavior, the psychiatrist is under no duty to withhold that information. His duty as a citizen includes both an obligation to protect his patient from the consequences of criminal behavior, and, under the appropriate circumstances, a duty to warn the intended victims of his patient's violence. ${ }^{246}$ He may fulfill this duty by recommending commitment. ${ }^{247}$

Whether a patient is competent to give consent constitutes another major ethical problem in commitment proceedings. Patients may agree to voluntary treatment even though they are mentally ill and incompetent to understand the implications of their agreement. Some psychiatrists feel that voluntary treatment for patients is better than involuntary commitment. ${ }^{248}$ They argue that voluntary patients suffer fewer abridgements of liberty, ${ }^{249}$ avoid the embarassment of an

him under the control of another or others because of alleged mental incompetence, or in an action to recover damages on account of conduct of the patient which constitutes a criminal offense other than a misdemeanor, or (b) upon an issue as to the validity of a document as a will of the patient, or (c) upon an issue between parties claiming by testate or intestate succession from a deceased patient.

N.J. STAT. ANN. §§ 2A:84A-22.3. See generally N.J. R. Evid. (Anno. 1980); N.J. R. Evid. 26A-2 comment 4 at 157-58.

245. It should be noted that this distinction is arbitrary and highly individual in application. Each therapist must decide for himself where to "draw the line" regarding the reporting of self-incriminating information. The doctor has to decide why the patient is revealing the information, what he wants the doctor to do with it and what course of action would be most beneficial to the patient. Where human life is lost or seriously in jeopardy, the psychiatrist does not have the same options as he does in the case of lesser crimes.

246. See, e.g., Tarasoff v. Board of Regents of Univ. of Cal., 17 Cal. 3d 425, 551 P.2d 334, 131 Cal Rptr. 14 (1976).

247. The psychiatrist is under a duty both to help his patient and to protect the intended victim. He is not under a strict duty to warn the victim if he can help his patient in a different way. Certainly, if the doctor is successful in hospitalizing the patient (either voluntarily or involuntarily), it is likely that the putative victim will be spared. However, if the doctor feels there is no proper treatment available in the hospital, he may face the dilemma of choosing to commit the patient anyway to prevent specific violence, or to inform the patient's family, the police, or the intended victim as possible alternatives to hospitalization.

He does have the duty, to the greatest extent possible, to prevent his patient from harming another person. By such prevention, he may not only save the intended victim's life but also spare his patient the difficulties attendant to killing another and facing subsequent criminal sanction. Neither of these latter options would be in the patient's best mental health interests. For an analysis of these issues, see Wexler, Patients, Therapists and Third Parties: The Victimological Virtues of Tarasoff, 2 INT'L J.L. \& PsrCH. 1 (1979).

248. See Applebaum, supra note 215. Most psychiatrists have long accepted the notion that voluntary patients were more successfully treated than were involuntary ones. Motivation for treatment is seen as a positive force, as contrasted to resistance common among involuntary patients.

249. On the other hand, it has been suggested that the distinction between "voluntary" and "involuntary" patients is often "illusory." Herr, Civil Rights, Uncivil Asylums and the Relarded, 43 U. CinN. L. REv. 679,722 (1974). "The 'voluntary' resident may even have fewer opportunities for discharge than those involuntarily committed. . . "Id. at 723. See generally Harper v. Cserr, 544 F.2d 1121, 1124 (Ist Cir. 1976); New York Ass'n for Retarded Children, Inc. v. Rockefeller, 357 F. Supp. 752, 756 (E.D.N.Y. 1973) 
open court proceeding, ${ }^{250}$ and are spared the publicity of such a hearing. ${ }^{251}$ Primarily, they believe that voluntary treatment is more effective than involuntary therapy. ${ }^{252}$ However, involuntary commitment does afford due process protection for the individual. The patient receives periodic court hearings to assess his need for continued hospitalization. But the ethical question arises whether the benefits of voluntary commitment outweigh the danger that such patients may be incompetent to sign their voluntary status and are thus "illegally" hospitalized. 253 They also may be unable to fully comprehend the meaning of their legal rights, for example, the right to contest commitment. Furthermore, they may not be competent to give consent for treatment, though they are often encouraged to sign the form for such treatment. ${ }^{254}$

The admitting psychiatrist may believe that voluntary commitment is "for the patient's own good." He may recognize the patient has no other place to go, and that if the patient returns to the community he may be unable to protect himself. ${ }^{255}$ Because these proceedings are not involuntary hearings, the patient does not have an attorney representing him, and is subject to the arbitrary, though sometimes beneficent, intentions of the assessing psychiatrist. ${ }^{256}$

Traditionally, the psychiatrist treats the patient only after the patient has been sent to the hospital. A psychiatrist's role changes if he is examining and assessing a person for hospitalization, especially if the criteria for commitment include "dangerousness" as well as mental illness. In this case the psychiatrist becomes a party to "incarcerating" the patient, a role which may jeopardize the subsequent doctorpatient treatment relationship. ${ }^{257}$ If the patient believes the docter has recom-

(subsequent citations omitted) (voluntarily admitted patients treated no differently than involuntarily admitted patients); Horacek v. Exon, 357 F. Supp. 71, 73 (D. Neb. 1973).

As the court noted in Cospito v. Califano, 89 F.R.D. 274, 380 (D.N.J. 1981), "[E]ven voluntary patients may be retained in the hospital against their will for observation periods and such persons are subject to formal, involuntary commitment procedures."

250. However, in most jurisdictions, the commitment hearing is now held in camera "unless good cause to the contrary is shown." See, e.g., N.J. CT. R. 4:74-7(e) (1982).

251. This argument appears questionable, in light of the predominance of in camera proceedings. See supra note 250 .

252. See, e.g., Rennie v. Klein, 462 F. Supp. 1131, 1144 (D.N.J. 1978) (“[T]he testimony has indicated that involuntary treatment is much less effective than the same treatment voluntarily received").

253. On the parallel question of a criminal defendant's competency to plead guilty, compare United States v. Masthers, 539 F.2d 721, 726 (D.C. Cir. 1976) and Seiling v. Eyman, 478 F.2d 211, 215 (9th Cir. 1973) (defendant's competency must be assessed "with specific reference to the gravity of the decisions with which [he] is faced") with State v. Norton, 167 N.J. Super. 229, 232, 400 A.2d 810, 811 (App. Div. 1979) (same test applies to competency to stand trial as to competency to plead guilty).

254. See, e.g., 50 PA. STAT. ANN. \$\$ 7201-07 (West 1980).

255. This specific matter is before the court in In re S.L., No. A.47 (N.J. App. Div., Feb. 24, 1982), reprinted in 15 CleaRinghouse REV. 381 (1981), cert. granted, N.J. Sup. Ct., May 20, 1982.

256. The oft-repeated admonition of Mr. Justice Brandeis is appropriate in this setting:

Experience should teach us to be most on our guard to protect liberty when the government's purposes are beneficent. Men born to freedom are naturally alert to repel invasion of their liberty by evil-minded rulers. The greatest dangers to liberty lurk in insidious encroachment by men of zeal, well-meaning but without understanding.

Olmstead v. United States, 277 U.S. 438, 471, 479 (1927) (Brandeis, J., dissenting).

257. See, e.g., Collins, The Rights of Mental Health Professionals, 44 BUll. MEnNinger Clinic 291, 294 (1980), noting that the psychiatrist has "the right to define the characteristics of the clinical setting that will best serve the purpose of goal achievement." Collins' concern is the role of the psychiatrist in aiding 
mended confinement, then the psychiatrist may have great difficulty establishing therapeutic rapport with that patient.

Placing the patient back in the same hospital under the care of the same doctor could pose treatment difficulties. The psychiatrist may be unable to conduct oneon-one psychotherapy or effectively work with the patient following a court decision to continue commitment. ${ }^{258}$ This is especially true if cross-examination at the commitment hearing leads to the inference that the psychiatrist does not "fully understand" his patient. If the psychiatrist explains his position to the patient prior to the hearing, the patient may, even after being represented aggressively and convincingly by an adversary attorney, return to the hospital for treatment in a more positive frame of mind. The patient may develop a sense of trust in the doctor with whom he did not agree, but whom he believes has his best medical interest in mind.

Nevertheless, most psychiatrists have traditionally disagreed with court involvement in the commitment decision. They argue that the law ill-advisedly takes away the responsibility of the psychiatrist who has more expertise in assessing what the patient needs. ${ }^{259}$ Such an attitude is inappropriate. As noted above, the legal proceedings protect the patient's liberty and protect the competent patient's right to make decisions about his treatment. ${ }^{260}$

The proceedings also provide legal protection for testifying psychiatrists. Commitment is not a strictly medical matter; it involves judicial concern with the liberty of patients, and psychiatrists must accept their increasingly limited role in these proceedings. The psychiatrist performs a legitimate function when he advises the court about the mental illness of the patient to be committed, about the clinical conditions under which a particular patient may be violent either to himself or to others, and about the effect of a particular mental illness on a patient's ability to function in a particular community or hospital setting. However, the courts are charged with making final decisions about commitment and retention based on statute, case law, and court rule.

\section{IV}

\section{CONCLUSION}

Freshman year college philosophy courses often include the proverb about the three Martians and the elephant. The moral to be drawn-that everything

\footnotetext{
the courts in detaining a person by permitting the hospital to become "an extension of the jail," a role he considers both inappropriate and antitherapeutic.

258. This, of course, assumes that such psychotherapy is, in fact, available in the institution to which the person is in danger of commitment. For perhaps a more realistic view, see Scott v. Plante, 641 F.2d 117, 131-32 (3d Cir. 1981), vacaled and remanded, 102 S. Ct. 3474 (1982) (plaintiff, a state hospital resident, met with treatment team 10 to 15 minutes per month, and had not received any psychiatric counseling for one-and-a-half years before trial).

259. On the importance of "turf" issues, see Issues in Debate: The Right to Refuse Treatment, I ADVOCACY Now 8 (1979).

260. This matter was put to rest in O'Connor v. Donaldson, 422 U.S. 563, 574 n.10 (1975), where the court labeled as "plainly unacceptable" the notion that it was somehow inappropriate for courts to involve themselves in treatment decisions "where 'treatment' is the sole asserted ground for depriving a person of liberty."
} 
depends on perspective-is equally applicable to the topic under consideration in this paper. The attorney's paramount ethical concerns center on his ability to represent competently his client's self-expressed interests and desires; on the other hand, the doctor's primary problem concerns his perceptions of the conflict between these wishes and medical need. In each instance, the choice of professional perspective-sometimes characterized as the adversary advocate or the benevolent care-giver-colors the determination of all issues. Although some of the ethical conflicts discussed cannot easily be resolved or disposed of with finality, it is critical for practitioners of both disciplines to come together to discuss and analyze their common problems in order better to share, and perhaps even try to harmonize, their perspectives. 